THE TEKLANIKA FORMATION - A NEW PALEOCENE VOLCANIC FORMATION IN THE CENTRAL ALASKA RANGE

By

Wyatt G. Gilbert, Virginla M. Ferrell, and Donald L. Tumer

GEOLOGIC REPORT 47

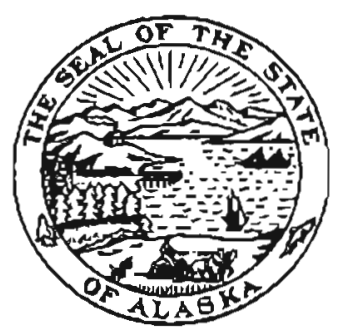


STATE OF ALASKA

Jay S. Hammond, Governor

Guy R. Martln, Commissioner, Dept. of Natural Resources

Ross G. Schapf, State Geologist

For sale Dy Alzsten Division of Geologjcal and Geophysical Surveys, P.O. Box B0007. College. 99708; 323 E. 41h Ave., Anchorage, 99501; P.O. Box 2438, Ketchikan, 89901; and Pouch M, Juneau, 99811 


\section{CONTENTS}

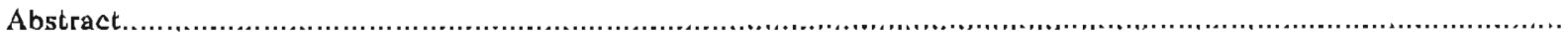

Introduction

Purpose.

Previous usage.

Present study.

General description of the Teklanika Formation.

Related igneous rocks.

Volcanic stratigraphy and petrology.

Upper Tek anik River sequence Summary

Unit A

Unit B.

Unit C

Unit D.

Unit E

Unit $\mathrm{F}$

Volcanic rocks of $\mathrm{Cathedral}$ and Igloo Mountains.

Volcanic rocks of Polychrome Mountain.

Volcanic rocks of upper Toklat River

Intrusive rocks.

Petrology

Felsic flows and intrusions

Pyroclastic rocks.

Mafic and intermodiate llows and intrusions

Geochemistry.

Geochronology..

Acknowledgments.

\section{ILLUSTRATIONS}

Plate 1. Geologic map and structure sections of Teklanika River-Polychrome Mountain area................ In pocke

Page

Figure 1. Distribution of Teklanika Formation and loc日tion of study area........................................

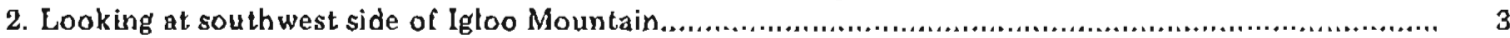

3. Lower part of upper Teklanika, sequence on east side of upper Teklanika River...............................

4. Looking north at eastern part of Polychrome Mountain........................................................... 6

5. Looking south at east-dipping andesite and rhyolite flows on east side of upper Toklat River................... 7

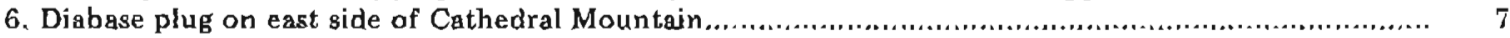

7. Photomicrograph of rhyolite flow from unit $F$ of upper Teklanika sequence................................... 9

8. Photomicrograph of thyolite flow from Cathedral Mountain...........................................

9. Photomicrograph of devitrified welded tuff from Cathedral Mountain displaying highly compressed shards and sanidine crystal fragments..

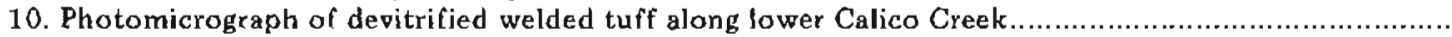

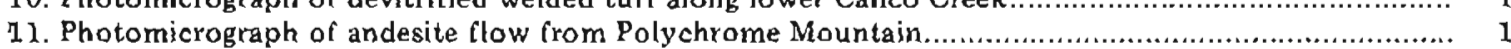

12. Photomicrograph of andesite flow from unit $\mathrm{E}$ of upper Teklanika sequence................................. 12

13. Chemical classification of nine volcanic rocks from Teklanika Formation after Irvine and Baragar, $1971 \ldots .$.

14. Alkalies-silica diagram with nine volcanic rocks from Teklanika Formation plotted

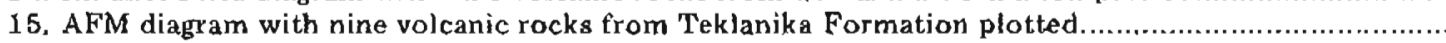

16. $\mathrm{Al}_{2} \mathrm{O}_{3}$ - Normative plagioclase diagram with nine volcanic rocks from Teklanika Formation plotted. 


\section{TABLES}

Table $\quad$ 1. Modes of selected rhyolite flows and felsic intrusions...................................................... 8

2. Modes of selected andesite and basait flows and mafic and intermediate intrusions....................... 11

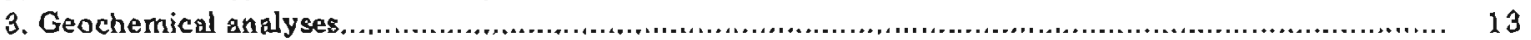

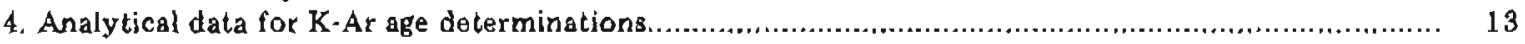




\title{
THE TEKLANIKA FORMATION - A NEW PALEOCENE VOLCANIC FORMATION IN THE CENTRAL ALASKA RANGE
}

\author{
By Wyatt G. Gilbert, ${ }^{1}$ Virginia M. Ferrell, ${ }^{1}$ and Donald L. Turner ${ }^{2}$
}

\begin{abstract}
A series of andesite, rhyolite, and basalt flows, felsic pyroclastic rocks, and related intrusive rocks covers about 165 square kilometers in the eastern part of Mount McKinley National Park. These rocks, once considered part of the Cantwell Formation, are now defined as the Teklanika Formation. The formation, which locally reaches a minimum thickness of 3,750 metars overlies the Cantwell Formation both conformably and unconformably. The type section of the Teklanika Formation forms the ridge east of the upper Teklanika River drainage and is composed of six conformable units.

Felsic volcanic hows are generally amygdaloidal porphyritic rhyolites with sanidine phenocrysts. Pyroclastic rocks are dominantly a combination of andesitic to rhyolitic vitric, lithic, and crystal welded tufls. Mafic flows range from olivine basalt to andesite.

Chemically, the Teklanika Formation is part of a calc-alkalt series and may be cogenetic with early Tertiary plutonic rocks in south-central Alaska.

Minimum radiometric ages of 60.6 and $41.8 \mathrm{~m} . \mathrm{y}$., together with an age of $57.2 \pm 4 . \mathrm{m} . \mathrm{y}$. from a related plug, suggest that eruption of the Teklanika Formation and orogeny occurred during Paleocene time.
\end{abstract}

\section{INTRODUCTION}

\section{PURPOSE}

The intent of this report is to name, describe, and radiometrically date a new volcanic formation-the Teklanika Formation-in the central Alaska Range, Alaska. This formation has prevlously been included in the Cantwell Formation. The Teklanika Formation is named after the Teklanika River, a majar tributary of the Toklat River, where the formation is particularly well exposed and where its thickest known section is found. The report does not completely describe the Teklanika Formation, however, because much of its outcrop area remains unmapped in detail.

\footnotetext{
${ }^{1}$ DGGS and Universlty of Alaska geology depariment. College. AK 99708 .

2 University of Alask Gophysical Institute and geology department, College, AK 99708 .
}

\section{PREVIOUS USAGE}

The Cantwell Formation was first recognized by Eldridge, who described the "Cantwell Conglomerate" as being "...a series of conglomerates and coarse sandstones which was encountered in the banks of the Cantwel] River [Nenana River] about 10 or 16 miles above the lower forks" (Eldridge, 1900, p. 16). The next reference to the Cantwell Formation was by Brooks (1911), who mapped and thoroughly described the Cantwell Formation in the Mount McKinley National Park area and first included volcanic rocks as part of the formation. He states: "In this area, especially toward the Nenana, lava tlows interbedded with the conglomerate are very prevalent. In some localities these volcanic rocks lorm over half of the thickness of strata exposed belonging to this formation. These lavas appear to be chiefly andesites, but also include rhyolites and basalts. That they were surface flows is indlcated both by their stratigraphic relations and by the amygdaloidal and columnar structure that some of them exhibit. Some tuffaceous beds also occur in this formation" (Brooks, 1911, p. 79).

The "interbeds," which Brooks describes on the next two pages of his report, are apparently metavolcanic rocks and quartz latite interbeds in the Mount SheldonWyoming Hills area, which ho probabiy mistakenly correlated with the andesite and rhyolite flows to the south (fig. 1). From r911 onward, workers have generally inciuded the volcanic rocks described in this paper as part of the Cantwell Formation (Capps, 1919, 1930, 1940; Reed, 1961; Wolfe and Wahrhaptig, 1970). Our study of these rocks, however, shows that the andesite-rhyolite flows lie above the sedimentary section of the Cantwell Formation, are in part unconformable on it, and form a distinct lithologic contrast with the sedimentary rocks of the Cantwell Formation. We do not wish to imply that the Cantwell Formation contains no volcanic interbeds. However, they are minor compared with sedimentary rocks of the Cantwell Formation; they also differ petrologically. The Cantwell Formation, therefore, is herein restricted to the general. ly conformable sequence of sandstone, siltstone, and conglomerate, as suggested originally by Eldridge (1900). 


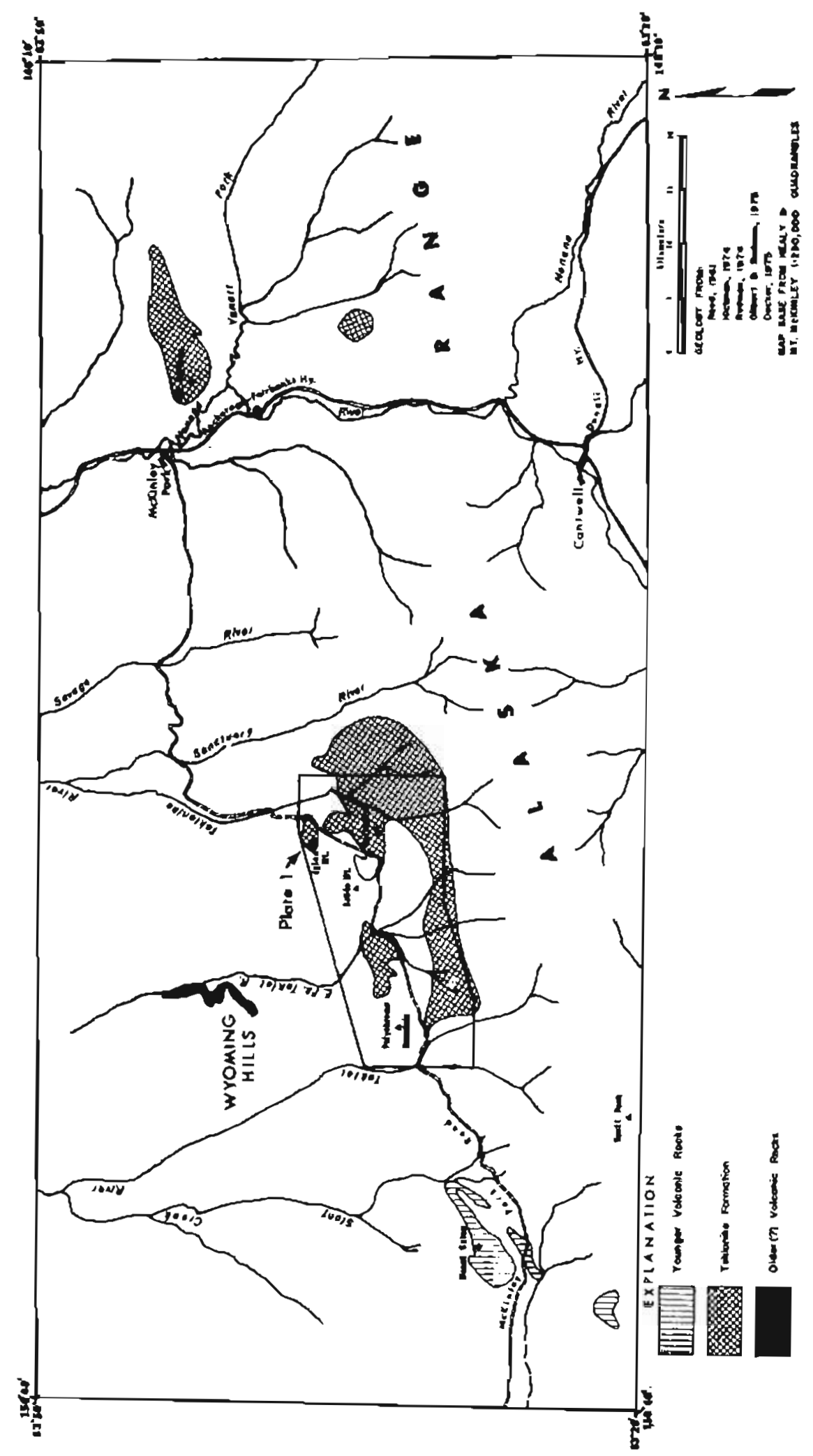

Figure 1. Dlstribution of Teklanika Formation and location of sludy area. 


\section{PRESENT STUDY}

This paper is the result of a 3-year study of the geology of the Healy C-6 quadrangle and immediate vicinity by Gilbert (Gilbert and Redman, 1975). In addition, petrologic examination of many of the vol. canic rocks by Ferrell and radiometric dating of three rock specimens by Ferrell and Turner are included as an important parl of the study.

\section{GENERAL DESCRIPTION OF THE TEKLANIKA FORMATION}

The Tekianika Formation is primarily composed of hows of andesite and rhyolite, with lesser amounts of basalt and pyroclastic rocks (igneous rock classification after Peterson, 1961). The formation covers aboul 165 square kilometers in the upper Toklat, East Fork, Teklanika, and Sanctuary River drainages in Mounl McKinley National Park (fig. 1), of which aboul 85 square kilometers has been mapped at 1:40,000 scale (Gilbert and Redman, 1975). In this area the 'Teklanika Formation is in sharp conformable or unconformable contact with the underlying sedimentary rocks of the Cantwell Formation. The contact is commonly marked by a 0.5. to 3.0-meter-thick light-colored lutf bed. On Igloo and Cathedial Mountains, the formation con. formably overlies a lenticular pebble-cobble-boulder conglomerate with abundant sandstone and volcanic clasts, and typical sandstone, siltstone, and conglomerate of the Cantwell Formation (Gilbert and Redman, 1975) (pl. 1, fig. 2). This upper Cantwell conglomerate overhes a thick sequence of sanoistone and siftstone and suggests that uplifl of a nearby volcanic and sedimentary lerrain took place concurrently witl the beglnoning of volcanism. On Polychrome Mounlahn, the gently folded Teklanika Formation lies with apparenl inconformily above a tightly folded sequence of Cantwell sandstone and conglomerate (pl. 1). Although this contact could be due of different mechanical responses by volcanic and sedimentary units during folding, no evidence of meclannical detachment was observed at the base of the voleanic sequence.

Basalt, andeslte, and minor pyroclastic rocks that cover 30 square kilometers and cap Mount Fellows in the lower Yanert River drainage just east of Mount McKinley National Park (Hickman, 1974) are here considered part of the Teklanika Formation (fig. 1). These rocks overlie the Cantwell Formation concordantly or with slight discordance (Hickman, 1974).

Quartz latite flows interbedded with conglomerate in the Wyoming Hills (fig. 1) differ in petrology and stratigraphic position from the Teklanika Formation (Redman, 1974); they are not considered part of the Teklanika Formation, but rather as interbeds within the Cantwell Formation. Volcanic rocks in the Mount

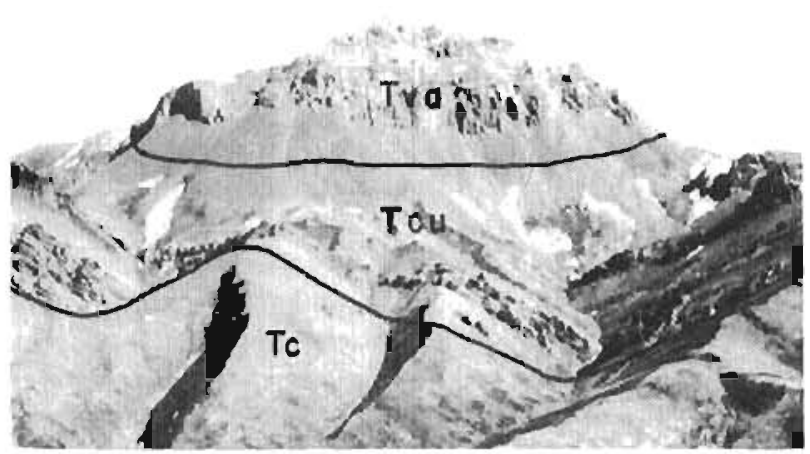

Figure 2. Looking at southwest side of Igloo Mountain. Tua, andesite and basalt flows: Tcu, upper conglomerate of Cantwell Formation; Tc, Cantwell Formation.

Galen area (fig. 1) that were thought by Reed (1961) to be part of the Cautwell formation are now known to be much younger (Decker, 1975). Hornblende andesite flows and shallow intrusions on Polychrome Mounlain (fig. 1) are also younger than the Teklanika Formation.

\section{AELATED IGNEOUS ROCKS}

Paleocene calc-alkaline volcanism in the central Alas. ka Range is only a small part of the extensive orogenesis and igneous activity that characterized the Canadian. Alaskan Cordillera during late Mesozoic and early Tertiary time (Lathram, 1973: Monger and others, 1972). In the Canadian Cordillera, extensive plutonism and volcanlsm occurred during uppermosi Cretaceous, Paleocelse, and Eocene time (Souther, 1967, Gabrielse, 1967).

In the western Aleutian Islands, major orogenesis accompanied by andesitic volcanisin also took place during Late Cretaceous and early Tertiary time (Coats, 1962). In the eastem Aleutian Islands and the Alaska Peninsula, early Tertlary deformation was accompanied by andesitic volcanism and intrusion of granitic to quarlz diorite batholiths (Burk, 1965).

In the northern Aleutian Range and southem and central Alaska Range, three episodes of intrusive activity during Jurassic, Late Cretaceous and early Ter. tlary, and mid-Tertiary time were accompanied by related volcanism (Reed and Lanphere, 1973). In the southem and central Alaska Range, Late Cretaceous and early Tertiary intrusions range mainly from quartz diorite to granite (Reed and Lanphere, 1973). The Teklanika Formation of the central Alaska Range is a series of calc-alkaline volcanic hows and tuff beds which are, perhaps, the surface expression of this Late Cre. taceous-early 'Tertiary intrusive epoch. 


\section{VOLCANIC STRATIGRAPHY AND PETROLOGY}

With in the study area the thickest known section of the Teklanika Formation underlies the ridge dividing the Calico Creek and the upper Teklanika River drainages ( $\mathrm{pl}$. 1). Other extensive exposures of the Cormation are found in the Cathedral-Igloo Mountains area, on the east side of Polychrome Mountain, and along the upper Toklat River. Coeval dikes, sills, and small stocks are scattered throughout this volcanic province. Complex faulting, overlying late Cenozoic sedimentary rocks, and extreme variation in volcanic stratigraphy make correlation between major areas of volcanic outcrop difficult. The stratigraphy of four representative areas will be described separately. The petrology of different parts of the formation is similar and will be discussed in one section (p. 7 ).

\section{UPPER TEKLANIKA RIVER SEQUENCE}

\section{SUMMARY}

This sequence forms the most complete known section of volcanic flows and is designated the type section of the Teklanika Formation (pl. 1, fig. 3). Six conformable units (units $A \cdot F$ ) with a minimum thickness of approximately 3,750 meters compose the sequence. The base of the upper Teklanika River sequence is 6-1/2 kilometers south of Calico Creek along the upper Teklanika River. Here the sequence is in probable fault contacl with the Canlwell Fornation. The top of the sequence is 5 kilometers south of Calico Creek along the east side of the Teklanika River, where the upper unit in the sequence is unconformably overlain by Qualernary deposits.

\section{UNIT A}

The lower part of the basal unit of the upper Teklanika River sequence is a series of dark-gray porphyritic and aphanilic basalt thows that form rugged topography on both sides of the upper Teklanika River, Individual flows range from 20 to 40 meters thick and are commonly jointed and tractured. In hand specimen, the porphyritic tlows contain fine- to medium-grained phenocrysts of pyroxene and homblende, altered to chlorite and set in an altered groundmass containing abundant plagioclase. This series of basalt flows exlibits the highest degree of deuteric alteration of any rocks in the lormation. The thickness of this series of flows is approximately 1,375 meters.

Overlying the series of basalt flows is an interval of interbedded mudstone, tuff, tuff breccia, and pillow basalt aboul 50 to 60 meters thick. These beds are present on both sides of the upper Teklanika River. The lowest bed in the interval is a 5-meter-thick darkgray to black carbonaceous mudstone that contains pieces of wood and plant material. For 20 meters above the dark mudstone bed, thin midstone heds 0.1 to 0.3 meters thick are interbedded with light-gray to white water-laid thyolite tuff and tulf breccia and gray to black tufl beds. The top of the interval is composed of about 30 meters of gray-green pillow basalt.

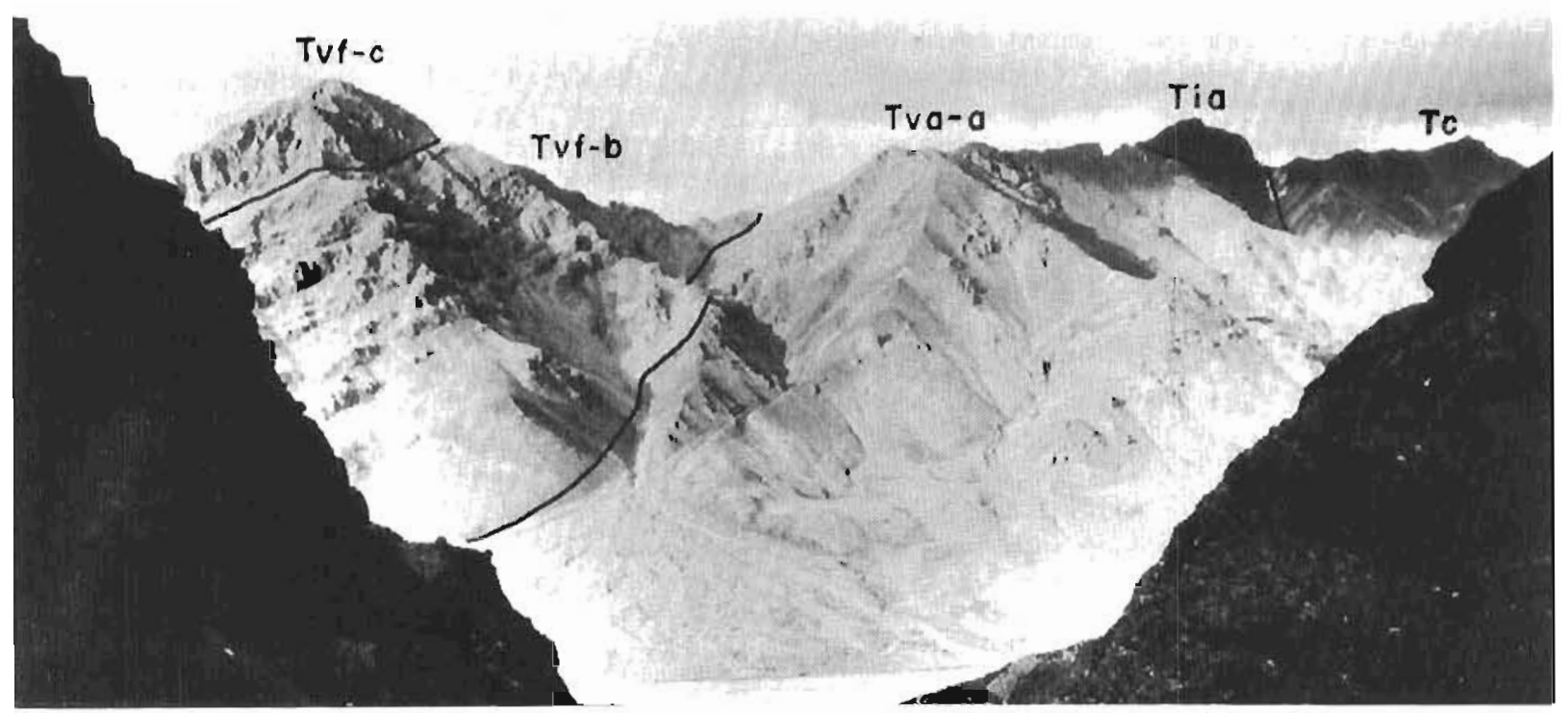

Figure 3. Lower part of upper Teklanika River sequence on east side of upper Teklanika River. Tva-a - unil $A$, Tuf-b unit B, Tuf-e - unit C of upper Teklanika River sequence: Tc - Cantwell Formation. Tia - mafic intrusion. 


\section{UNIT B}

In this unit about 40 resistant nows of brown. and purple-weathering gray andesite, each 2 to 5 meters thick, alternate with beds of less resistant tuff and tulf breccia, 5 to 10 meters thick (fig. 3). The unit is about $\$ 00$ meters thick.

\section{UNIT C}

This unit is composed of a rugged series of purple. weathering light-gray microcrystalline rhyolite flows 20 to 50 meters thick. The rhyolite flows are similar in lithology to flows in unit B, but differ in thickness and also lack interbedded tuff and tuff breccia. The unit is from 545 meters to 600 meters thick. West of the upper Teklanika River, units $\mathrm{B}$ and $\mathrm{C}$ merge into a composite unit with beds of tuff and tuff breccia scattered throughout.

\section{UNIT 0}

This unit, composed of light-tan veslcular porphyroaphanitic rhyolite flows 5 to 50 meters thick, is exposed on bolh the east and west sides of the upper Teklanika River. Interbeds of amygdatoidal olivine-augite basalt and andesite, 5 to 10 meters thick and locally displaying columnar jointing, are common in this unlt. Scattered beds of rhyolite crystal tuff are asso present. The unit is about 600 meters thick.

\section{UNIT E}

This unit contains a series of dark-brown-weathering dark-gray olivine-augite basalt and andesite nows, 5 to 40 meters thick. The lops of the flows are commonly anygdaloidal, with vesicles filled with calcite, chalcedony, or quartz. Interbeds of dark-gray agglomerate, containing clasts of mafic and intermediate volcanic rocks set in a dark-gray vesicular glassy groundmass, commonty overlie the flows. Beds of rhyolite tuff and tuff breccia 1 to 2 meters thick are intermittently interbedded with the basalt and andesite flows. Scat lered flows of magnetite-rlch basalt crop out east of the upper Teklanika River. The unit is from 430 to 670 meters thick.

\section{UNIT F}

This unit is composed of a thick flow of light-brownweathering light-gray porphyritic rhyolite with sanidine phenocrysts. The base of the unit is marked by a 2 . meter-thick black-and-whlte bed of obsidian. The unit has a minimum thlckness of 60 meters and is unconformabiy overiain by Quatemary alluvial deposits.

\section{VOLCANIC ROCKS OF CATHEDRAL AND IGLOO MOUNTAINS}

A thick series of volcanic rocks caps Igloo Mountain, is exposed along Tattler Creek, and crops out over most of Cathedral Mountain (pl. 1). Two volcanic units are present: a lower andesite unit and an upper rhyolite unit. A major northeast-trending fault on Cathedral Mountain repeats the two units. Small intrusive dikes and sills are found intruding the extrusive rocks.

The andesite unit is present on both Cathedral and Igloo Mountains, where it conformably overlies the Cantwell Formation. On Igloo Mountain, about 12 brown-wealhering gray aphanitic vesicular andesite flows are interbedded with minor laterally disconlinuous tuff beds (fig. 2). 'The turf beds are 0.5 to 1.0 meters thick, light green, and vesicular. On the northeast side of Igloo Mountain, a 2-meter-thick light-gray tuff bed marks the contact belween the Teklanika and Cantwell Formations.

On the west side of Cathedral Mountain and in Tattler Creek, andesite and basall flows are gray to black, aphanitic to fine grained, and vesicular. In this area, basalt flows are common in the lower portion of the unit. The andesite and basalt nows weather reddish brown and commonly exhibit columnar jointing. The contact with the underlying Cantwell Formation is marked by interbedded tuffaceous sedimentary rocks and volcanic fows, and is placed at the base of a 3 meter-thick light-colored tuff bed. The upper part of the andesite unit on Cathedral Mountain and along Tattier Creek contains interbedded dark-weathering rhyolite flows, similar to those in the overiying rhyolite unit. The thickness of the andesite unit ranges from 500 meters on Cathedral Mountain to 770 meters on Igloo Mountain.

A series of rhyolite flows and pyroclastic rocks overlies the andesite unit south of Tattler Creek and on Cathedral Mountain. The flows are siliceous microcrystalline to hyaline rocks from 3 to 25 meters thick. The flows south of Tattler Creek and on the northern and central parts of Cathedral Mountain are intruded by many small dikes and sills. Rhyolite crysta-lithic tuff and volcaniclastic lithic sandstone are found interbedded with the rhyolite flows on the central part of Cathedral Mountain. The minimum thickness of the rhyolite unit reaches 500 meters on Cathedral Moun. tain.

East of the Teklanika River and north of a major east-west-trending fault 3 kilometers south of the mouth of Calico Creek are two units that appear to be in fault contact with one another. The southern unit is made up of a variety of interbedded pyroclastic beds and rhyolite flows that are 50 to 60 meters thick. This unit has a minimum thickness of about 1,100 meters. Common lithologies observed include: andesitic lithic-crystal weld- 
ed tuff, medium- to coarse-grained volcaniclastic lithic sandstone with luff and feldspar fragments, porplyyroaphanitic rhyolite llows with altered microphenocrysts of sanidine, and other cryptocrystalline to microcrystalline nows with fine- to medium-grained plagioclase phenocrysts.

The northern unil along the lower part of Calico Creek includes at least 1,500 meters of augite basalt and pyroclastic rocks in beds 10 to 20 meters thick. The pyroclastic rocks are in part composed of crystal-Jithic weided tuff, but the relative abundance of each rock type is unknown. The relationship of these two units to the volcanic rocks on Cathedral Mountain, or to the upper Teklanika sequence to the south, is unclear.

\section{VOLCANTC ROCKS OF POLYCHROME MOUNTAIN}

Two series of rliyolite flows sandwich a sequence of andesite flows on Polychrome Mountain (pl. 1). In both series, flows of porphyro-aphanitic flow-banded rhy. olite contain inlerbeds of rhyolite crystal tuff and lithic welded tuff. Because scattered exposures of rhyolite are found between Polychrome Mouncain and the rhyolite unit exposed along Tattler Creek, the rhyolite flows on Polyclirome Mountain may be corr. tinuous with the upper rhyolite unit on Cathedral Mountain. The lower series of rhyolite flows forms an angular unconformity with the underlying Cantwell Formation and ranges in thickness from 0 to 350 meters (fig. 4). The upper series of rhyolite flows has a maximum exposed thickness of 750 meters.

Separating the lwo units of rhyolite flows is an andesite unit consisting of about 10 bows, each from 3 to 30 meters thick. The nows become thinner in the upper part of the unit. The flows are vesicular and bear geodes containing lemalite, chalcedony, and calcite or quark or both. The thickness of the unit ranges from 175 to 500 meters.

\section{VOLCANIC ROCKS OF UPPER TOKLAT RIVER}

I'hree to 5 kilometers south of Polychrome Mountain along the east brancli of the Toklat River are two eastdipping volcanic units (pl, 1, lig. 5). The lower unit is composed of interbedded andesite and rhyolite nows that confonnably(?) overlie the Can Lwell Formation; the upper unit is predominantly rhyolite.

The lower andesite-rlyyolite unit is 1,350 meters thick and contains altemating andesite and rhyolite nows from 5 to 20 meters thick. The andesite nows are highly vesicular and often contain geodes. Some of the rhyolite flows nay be devitrified welded rhyolite tulf with microphenocrysts of quartz, sanidine, and biotite.

East of and above the andesite-rhyolite unit is a series of porphyro-aplianitic rhyolite flows. This unil has a thickness of at least 555 meters. Scattered exposures suggest that these nows merge with rhyolite units in the upper Teklanika River area.

\section{INTRUSIVE ROCKS}

Most of the intrusive rocks in the area are mafic and intermediate sills, dikes, and small plutonic bodies (pl. 1). Intruding unit $A$ of the upper Teklanika sequence is a small mafic plug, On Cathedral Mountain about 0.5 kilometers east of the mouth of Tattler Creek is a fineto medium-grained quartz-bearing diorile; a diabase plug and a series of fine-grained augite diabase sills

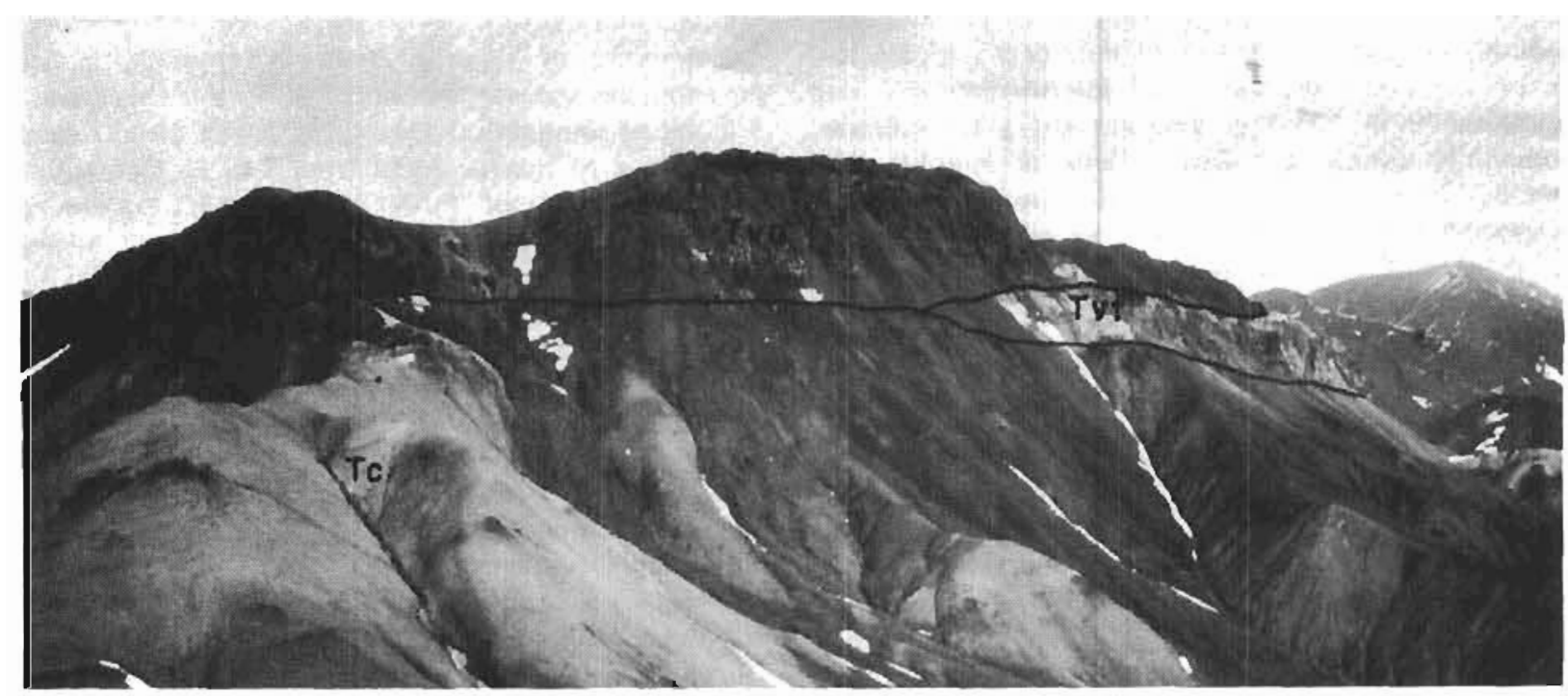

Figure 4. Looking north at eastern part of Polychrome Mountain. Tva - andesile and basall flows, Tuf - rhyolite flows, Tc-Canlwell Formation. 


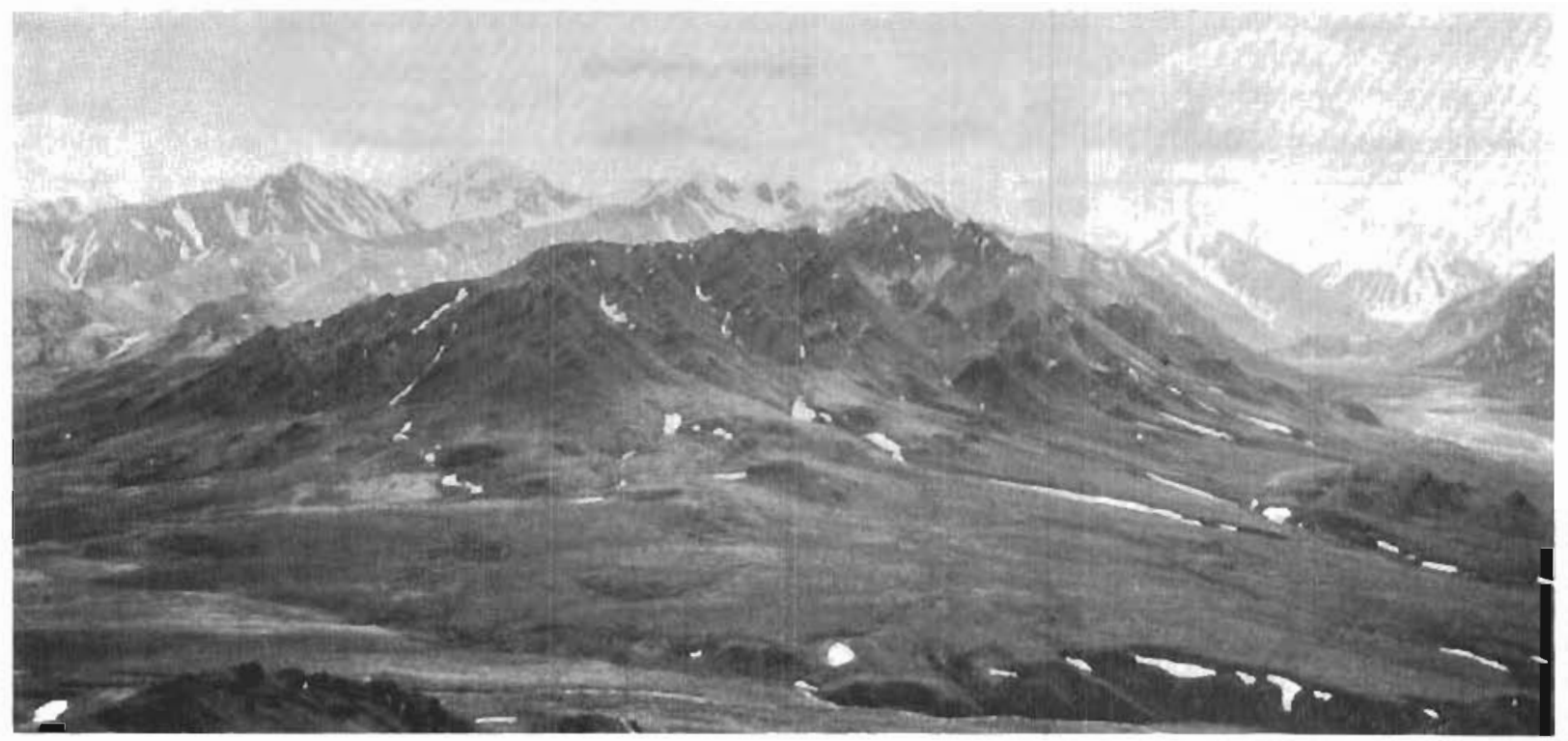

Figure 6. Looking south al east-dlipping indesite and rhyolite flows on east side of upper Toklat River.

are exposed along the east side of the mountain (fig. 6).

A small fine- to isedium-grained quartz-bearing diorite plug covering 0.15 square kilometers is found on Polychrome: Mountain along the Denall Highway, and an east-west-trending diabase dike is exposed for 3 kilometers on the north side of the mountain. Numerous malic dikes and sills, ranging from 1 to 10 meters thick, are found throughout the Cantwell and Teklanika Formations. They are generally aplianific and oflen exhibil a directive fabric duc to flow.

Folsic intrusive rocks are less common than malic intrusive rocks in the region, but phyolite to quart? latite dikes, sills, and small plugs crop out throughout the area of the Teklanika Formation. A 25-meter-thick porphyro-aphanitic rhyolite dike cuts unit $A$ on the east side of the upper Teklanika RIver. On the western side of Polychrome Mountain, a rhyolite sill 14 meters thick has intruded the Cantwell Formation. Three hypabysal porphyro-aphanitic rhyodacite to quarts, latite plugs are present near the mouth of Tattler Creek.

Most of these intrusive rocks wie probably feeders to the volcanic rocks of the Teklanika Formation. The intrusions are widely sentlwred, suggesting that the stratigraphically heterogeneous Teklanika Formation was formed around many centers of eruption.

\section{PETROLOGY}

\section{FELSIC FLOIVS AND INTRUSIONS}

Most of the folsic volcanic flows are porphyrilic rhyolites (Lable 1). The rocks have a microcrystalline to lyaline groundmass and a faint planar labric caused by eicher segregation of mafic and siliceous minerals or by the aligrument of feldspars.

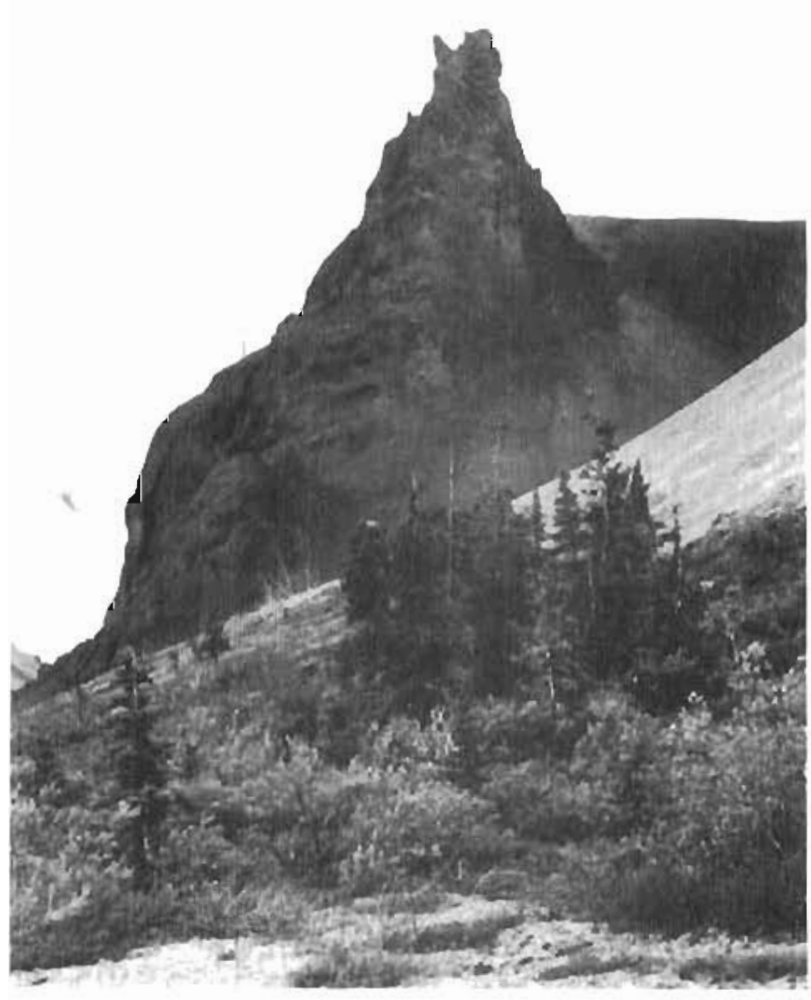

Figure 6. Diabase plug on enst side of Cathedral Moun. tain.

In the rhyolite flows, high sanidine $\left(2 \mathrm{~V}-0.40^{\circ}\right)$ occurs as euhedral to subhedral phenocrysts and nicrophenocrysts (lig. 7), añu may contain simple Carlsbad 
Table 1. Modes of selected rhyolite flows and felsic intrusions (based on 300 points caunted per thin section and estimation of ground mass composition)-in percent.

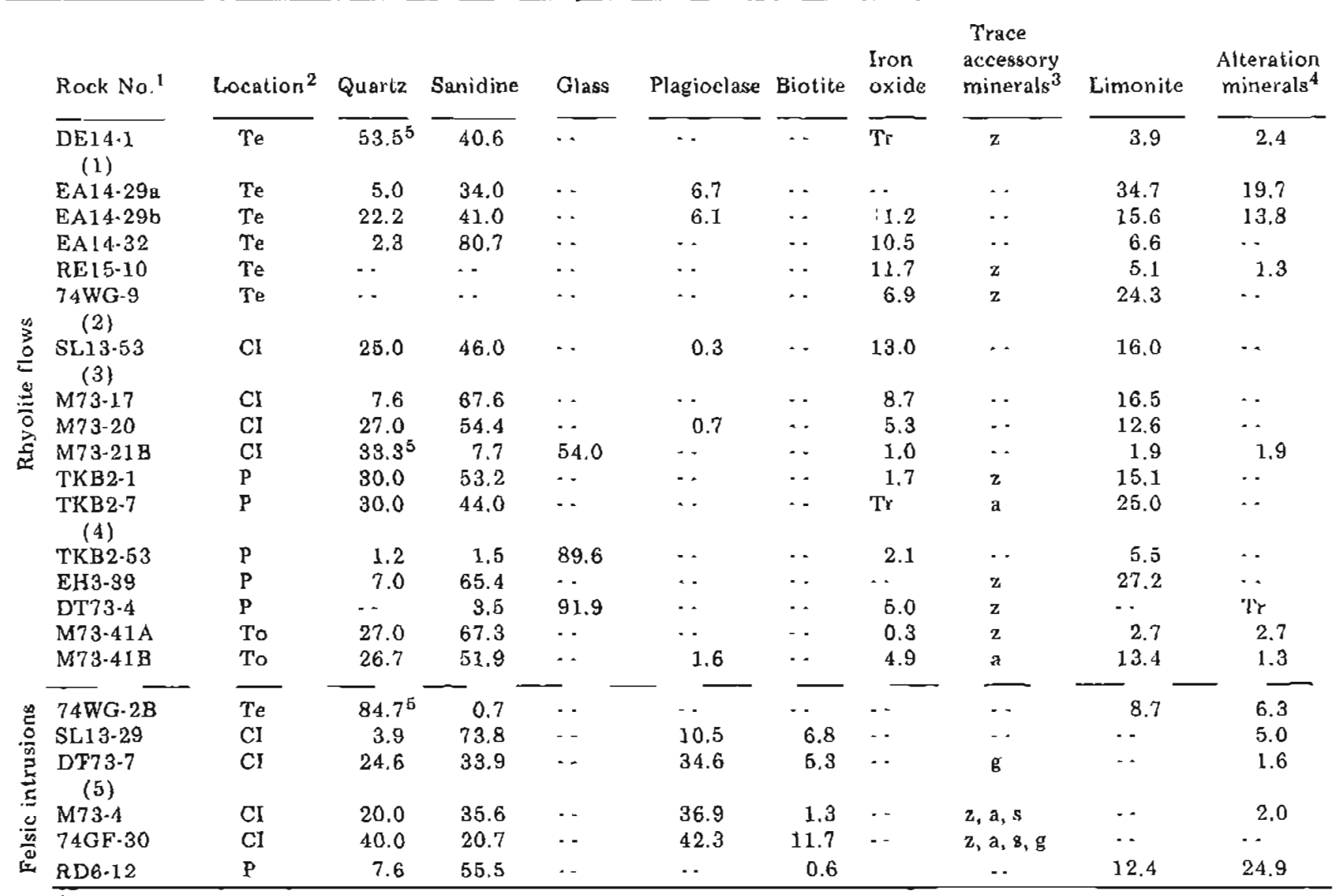

$1(1)$ a Geochemical analy gls numberi refers to preceding sample

2 Te $=$ Upper Teklanlka sequedce

CI $=$ Cathedral-Igloo Mountain area

$P=$ Polychrome Mountain area

To $=$ Upper Tokla Fiver area

Tr = Trace amount

$8_{2,}=$ Zircon

$a=$ Apatile

$s=$ Sphenk

$g=$ Gamet

4 Primarjy calcite, sericite, and kaolinile

Sincludes tridy mito

twins. Plagioclase (An content not optlcally determinable) is found as a minor subhedral microphenocryst which may be surrounded by cumulophyric sanidine. Quart2 rarely occurs as phenocrysts, but is common as a late interstitial constituent. Tridymite and cristobalite commonly fill vestcles. Iron oxide minerals are abundant. Microcrystalline $(0.01$ to $0.2 \mathrm{~mm})$ minerals include subhedral to euhedral sanidine and interstitial quartz, and primary spherulites of microcrystalline quarti, sanidine, and cristobalite surrounded by limonite are common (fig. 8). Plagioclase is occasionally present in the groundmass. Zircon and rarely apatite occur in trace amounts. Secondary minerais include kaolinite, calcite, and biotite; kaolinite, wholly or in part, commonly replaces groundmass and sanidine phenocrysts.
Petrology and texture of nearby felsic intrusive rocks strongly suggest they are related to the rhyolite flows (table 1). The rhyolite dike in unit $A$ of the upper Teklanikg sequence and the rhyolite sill on the west side of Polychrome Mountain are hypidiomorphic and holocrystalline. Phenocrysts of anhedral tine-grained quartz, fine-grained biotite, and tine- to medium-grained anhedral to euhedral high sanidine occur in a groundmass of sanldine, quartz, and limonite. Biotite commonly has a reaction rim conlalning magnetite, and deuteric alteration of sanidine phenocrysts and ground. mass to sericite and kaolinite is common. The rhyolite dike and sill are similar in texture and mineralogy to the rlyolite flows in the Teklanika Formation.

Three small hypabyssal quartz latite plugs near the mouth of Tattler Creek may ejther be related to volcanic flows of represent a separate igneous event. In these rocks, fine- to medium-grained subhedral labradorite phenocrysts and fine- to medium-gralned subhedral sanidine phenocrysts are set in a microcrystalline to fine-grained groundmass of sanidine, quartz, and biotite. Apatite, zircon, and sphene are common accessory minerals. Trace amounts of anhedral garnet are found in the plugs. If these rocks are derived from the same magma as nearby flows, they probably are the result of a mixing of andesite and rhyolite magrnas. 


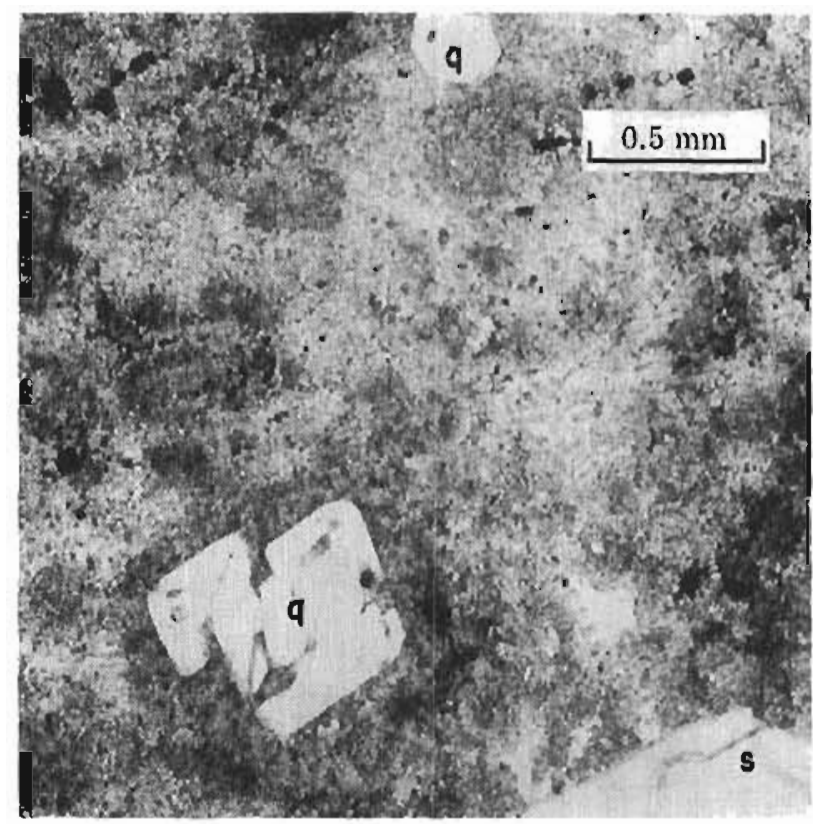

Figure 7. Photomicrograph of thyolite flow from nnit F of upper Teklanika sequence. Phenocrysts of quartz and sanidine are set in a quartz-cristobalitesanidine groundmass. Cristobalite forms the dark halo around the resorbed quart\% plienocryst. q quartz, s - sanidine. Plane polarized light.

\section{PYROCLASTIC ROCKS}

Pyroclastic rocks are most commonly found interbedded with relsic nows and rarely with mafic Mows. They are dominantly a combination of andesile to rhyolite vitric, lithic, and crystal welded tuffs: Some graded volcaniclastic sandstone beds containing tuf. faceous [ragments suggest deposition in a quiet aquatic environment.

Welded tuffs contain either crystals or lithic fragments, or both, in a devitrified groundmass of shards and pumice fragments (figs. 9 and 10). Crystal fragments include high sanidine $\left(2 \mathrm{~V}=30-35^{\circ}\right)$, calcic plagioclase (An 36-74) and rarely, quartz. Sanidine and plagioclase are commonly found in the same rock. Opaque oxides are common accessory minerals in the groundmass. Glass shards have been contorted and nattened, and range from 0.1 to $0.5 \mathrm{~mm}$ in length. The shards commonly display axialitic or splerulitic textures due to devitrification to cristobalite. A wide variety of cognate lithic fragments are derived from nows or tuffaceous rocks; they range from 0.05 to $0.08 \mathrm{~mm}$ in length.

\section{MAFIC AND INTERMEDIATE FLOWS AND INTRUSIONS}

Mafic flows range from olivine basalt to andesite, bul most flows are andesites (Lable 2 ). These rocks are

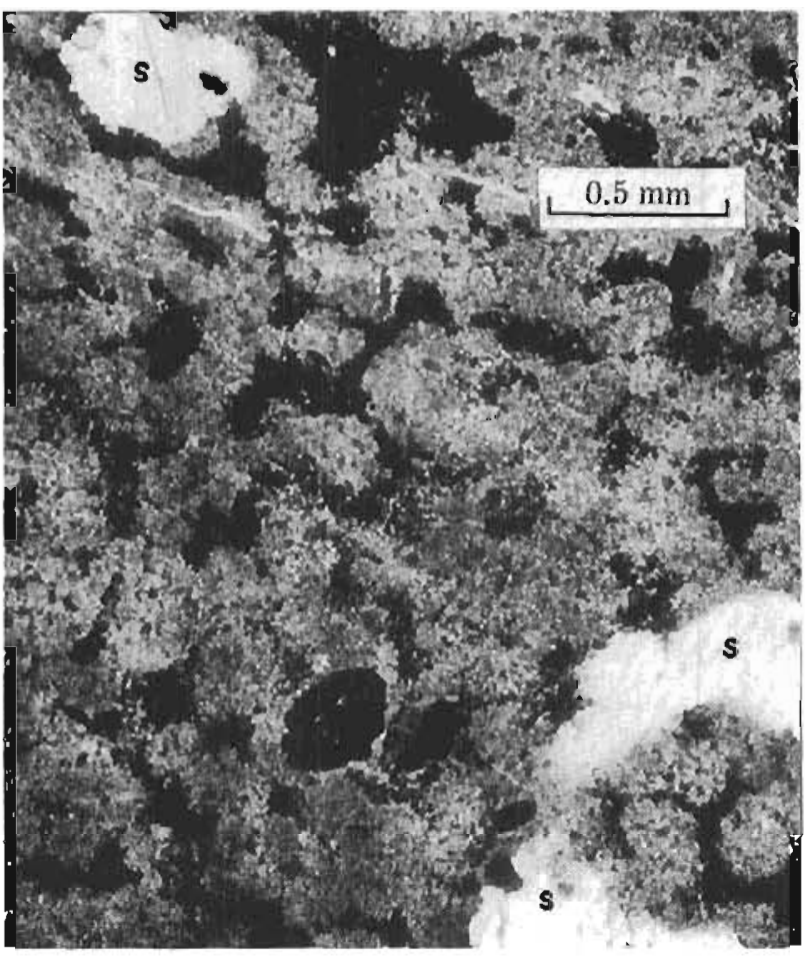

Figure 8. Photomicrograph of rhyolite flow from $\mathrm{Ca}_{2}$ thedral Mountain. Gioundmass of quartz-feldspar spherulites and limonjte exhibils faint flow foliation. $s$ - sanidine phenocryst. Plane polarized lighl.

hypidiomorphic and holocrystalline (figs. 11 and 12). Plagioclase (An 42.60) is generally subhedral, tabular, and twinned, and exhibits resorbed crystal outlines. Complex zoning, with calcic plagioclase cores, is common. Minor interstitial sanidine is occasionally present. Augite $\left(2 \mathrm{~V}=30-40^{\circ}\right)$ is commonly' ophitic, anhedral, and fine to medium grained. Olivine ( $\left.F_{0} 60-65\right)$ is a common fine-grained constituent and occasionally forms mediumgrained phenocrysts. Alteration of the olivine to serpentine and iddingsite is ubiquitous. Ilmenite and magnetite are usually present, and apatite and zircon are rrequent accessory minerals. A few basalt and andesite flows on Cathedral Mountain exhibit a directive cabric due to the orientation of the plagiociase crystals. Dense magnetite-rich (36-39\%) basalt flows are a minor part of unit $E$ in the upper Teklanika sequence. These rocks also contain fine-grained plagioclase, oljvine, and augite. Secondary minerals observed in the basalt and andesite fows are chiefly sericite, calcile, and biolite.

Numerous mafic and intermediate sills, dikes, and small plutons cut both the Teklanika Formation and the nearby Cantwell Formation. On the southwest side of Cathedral Mounlain, a small fine- to mediumgrained quarly-bearing dionte plug contains subliedral tabular andesine and medium-grained subhedral sanidine $\left(2 \mathrm{~V}=35^{\circ}\right)$. Augite is the only primary mafic silicate present, and hydrothermal alteration has introduced 


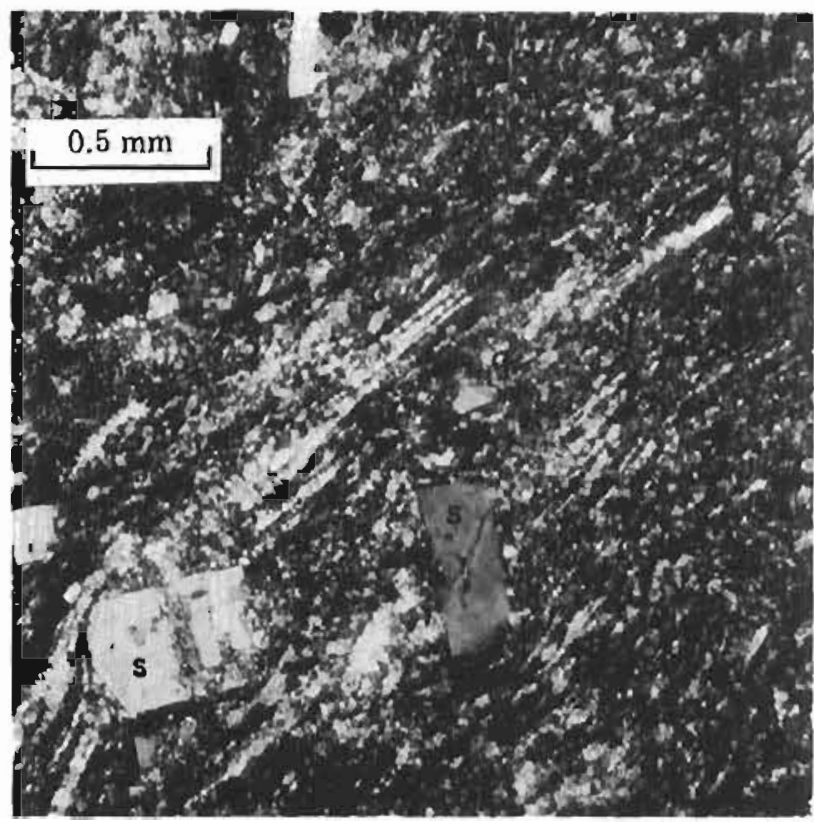

Figure 9. Pholomicrograph of devitrilied welded luff from Cathedral Mountain displaying highly compressed shards and sanidine crystal rragments. \& . sanidine, $q$ - quartz. Crossed nicols.

calcite and biotite,

On the east side of Cathedral Mountain are a finegrained hypldiomorphic and holocrystalline diabase plug and numerous sills. The plug and silis contain subhe lral labradorite, anhedral augite, and ilmenite. Magnetite and apatite are very fine-grained accessories, and secondary biolite has been hydrothermally introduced.

A quartz dionite plug on Polychrome Mounlain is holocrystalline, fine to medium grained, inequigranular, and hypidiomorphic. The plug contains medium-grained subhedral andesine (An 38.44 ), interstitial alkali feldspar (surrounding the plagioclase grains), anhedral olivine (Fo 45-50), anhedral medium-grained augite, and subhedral to euhedral quartz. Apatite is fine grained, euhedral, equant to prismatic, and makes up 2 to 4 percent of the plug. Accessory minerals include magnetite, ilmenite, hemalite, zircon, and garnel.

An easl-west-trending ollvine-homblende gabbro dike crops out on the northem edge of Polychrome Mountain. It contrins fine- to medium-grained subhedial tabular labradorite. Homblende is completely replaced by magnetite, leaving relict fine. to medium-grained subhedral to euhedral hornblende outlines. Augite is subhedral to euhedral, cumulophyric, and zoned. Olivine is both fine grained and anhedral and medium-grained, ellhedral, and zoned.

Many other andesite and basalt dikes cut the volcanic nows and the Cantwell Formation. The dikes are dark gray, aphanitic, and equigranular. Plagioclase accoun is for about 70 percent of the rocks, with the rest being mainly limonite and opaque oxides. The dikes are

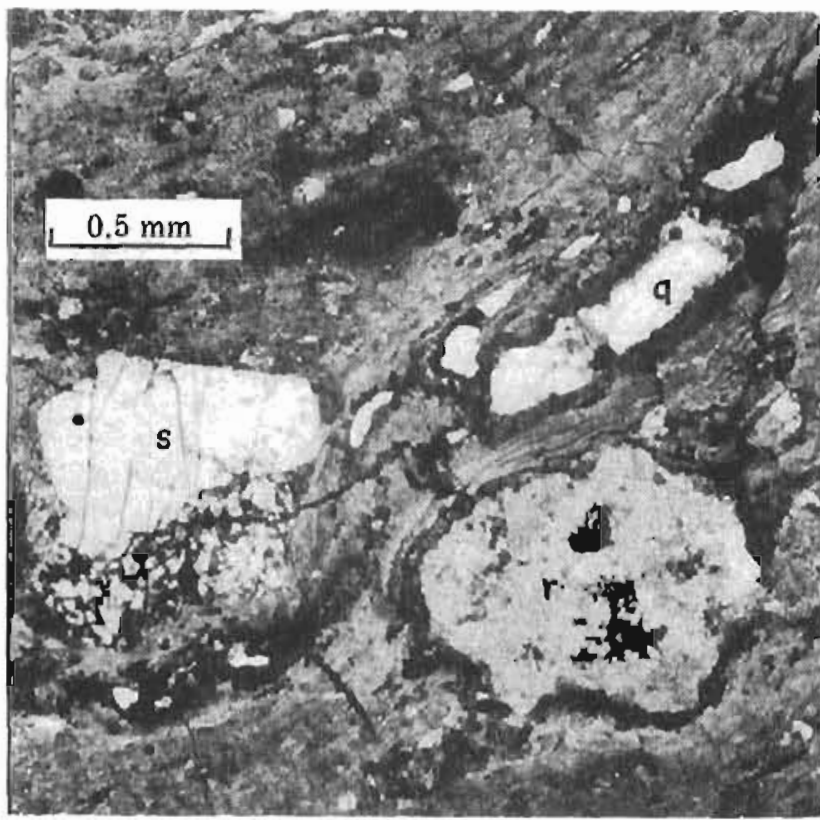

Figure 10. Pholomicrograph of devitrilied welded turf dong lower Calico Creek. Extreme-compression and stretching has nearly eliminated shard texcure, $r$. rhy. olite rock fragment, s - sanidine fragmenk, 4 - quariz. Plane polarized light.

commonly partially altered to calcite, sericite, and chlorite. Both geologic setting and pctrology suggest that the andesite and basall dikes and sills, together with the other mafic and intermediate intrusions discussed, have direct extrusive equivalents.

\section{GEOCHEMISTRY}

Chemical data from 11 samples surisest that the Teklanika Formation forms a calc-alkaline volcanic suite as is commonly found in continental margin volcanic belts (Green and Ringwood, 1968; Jakes and White, 1972). This conclusion is based on the cliemical classification of Irvine and Baragar (1971), whereby volcanic rocks are classified into three main types: subalkaline, alkaline, and peralkaline, with subalkaline rocks being subdivided into a tholeitic basalt series and a calc-alkali series. Chemical analyses and CIPW norm values for the 11 samples are given in table 3 . Four of the samples were modally classified as rhyolite, four as andesites, and one as a basalt; one sample is from a quartz-latite olug and one is from a quartz-bearing dionte pluton. A chemical classification of the nine volcanic samples analyzed according to the method of lrvine and Barager (1971) is given in flgure 13.

Chemically, the volcanic rocks of the Teklanika Formation are subalkaline, as suggested by the presence of normative quarty, and hypersthene and by their position on the alkalies-silica diagram (fig. 14). Furthermore, an AFM plow (ng. 15), which shows a lack of 
Table 2. Modes of selected andesite and basall hous and mafic and intermediate intrusions (bosed on 300 point count)-in percent.

\begin{tabular}{|c|c|c|c|c|c|c|c|c|c|c|c|c|c|c|}
\hline Rock No. & Location $^{2}$ & Quartz & Saoidine & Plagioclase & Hornblende & Augite & Olivine & $\begin{array}{l}\text { Iron } \\
\text { oxides }\end{array}$ & $\begin{array}{l}\text { Accessory } \\
\text { minerals }\end{array}$ & Serpentine & Iddingsite & Limonite & $\begin{array}{l}\text { Other } \\
\text { alteration } \\
\text { minerals }\end{array}$ & \\
\hline$\overline{\mathrm{DE} 14-2}$ & $\mathrm{Te}$ & $\cdots$ & $\because$ & $\overline{43.3}$ & $\cdots$ & 0.7 & 2.7 & $\overline{39.3}$ & $0,3 a$ & 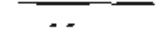 & $\cdots$ & $\cdots$ & 13.7 & \\
\hline DE 14-6 & Te & $\because-$ & $\cdots$ & 61.3 & $\ldots$ & 10.9 & 3.0 & 8.2 & $0.7 a$ & 1.7 & - & 7.6 & 6.6 & \\
\hline EA14-36 & $\mathrm{re}$ & $\therefore$ & $\cdots$ & 40.8 & $\therefore$ & 17.7 & $\ldots$ & 6.4 & $\ldots$ & $\therefore$ & 34.7 & $\ldots$ & 0.3 & \\
\hline CC15-5 & $\mathrm{Te}$ & $\cdots$ & $\cdots$ & 41.5 & $\cdots$ & 5.3 & 11.4 & 37.1 & $\operatorname{Tr} \approx$ & - - & 0.6 & - & 4.0 & \\
\hline $\operatorname{ccl} 5-6$ & $\mathrm{Te}$ & - & $\cdots$ & 57.6 & . & 16.6 & 3.8 & 4.5 & $0.3 \mathrm{a}$ & 2.9 & 10.9 & $\cdots$ & 3.5 & \\
\hline RE15-30 & $\mathrm{Te}$ & $-\cdot$ & $\because$ & 20.0 & $\cdots$ & $\therefore$ & $\cdots$ & $\cdots$ & $\therefore$ & $\therefore$ & $\therefore$ & . & 80.0 & \\
\hline $\begin{array}{c}\text { REI5-38 } \\
(6)\end{array}$ & Te & $3 r$ & $\cdots$ & 59.5 & $\cdots$ & 17.9 & -+ & 7.0 & $\cdots$ & $\cdots$ & $\cdots$ & $\cdots$ & 16.6 & \\
\hline $74 W G-4 A$ & $\mathrm{Te}$ & - & - & 61.7 & - & 20.0 & 6.3 & 2.5 & $0.9 \mathrm{a}$ & 5.4 & 1.6 & - & 1.6 & \\
\hline $74 W G-4 B$ & $\mathrm{Te}$ & - & - & 56,6 & -- & 11.0 & 1.0 & 8.0 & Tra & 12.0 & 3.6 & $\mathrm{Tr}$ & 12.6 & \\
\hline $\begin{array}{c}74 W G-6 \\
(7)\end{array}$ & $\mathrm{Te}$ & $\therefore$ & $\cdots$ & 52.3 & $\cdots$ & 15.4 & 4.4 & 6.0 & -. & 14.1 & 3.7 & - & 4.7 & \\
\hline $74 W G-14$ & $\mathrm{Te}$ & $\cdots$ & $\cdots$ & 62.3 & - & 13.0 & 5.3 & 1.6 & 0.7 a & 15.0 & . & - & 2.0 & \\
\hline JR 1 2-43 & $\mathrm{CI}$ & $\cdots$ & $\cdots$ & 54.8 & $\cdots$ & - & $\cdots$ & 12.5 & $\cdots$ & $\cdots$ & $\cdots$ & - & 32.8 & \\
\hline RJ13-48 & CI & $\cdots$ & 0.3 & 55.4 & $\cdots$ & $\cdots$ & $\cdots$ & 0.3 & $\operatorname{Tr} a$ & $\ldots$ & .. & 29.8 & 13.8 & \\
\hline Rdis-51 & CI & . & $\therefore$ & 46.6 & + & 12.8 & 32.6 & 8.0 & Tra & $\cdots$ & $\cdots$ & -- & 0.7 & \\
\hline $\begin{array}{l}\text { SL13 44A } \\
\text { (B) }\end{array}$ & $\mathrm{Cl}$ & $\cdots$ & $=$ & 59.6 & $\cdots$ & 20.1 & 0.6 & 2.1 & 0.6 & $\cdots$ & $x 4.5$ & $\cdots$ & 2.5 & 可 \\
\hline SL $33-44 B$ & Cl & 0.6 & $\cdots$ & 68.2 & -- & 37.7 & 14.3 & 4.5 & $1.2 \mathrm{a}$ & - & .. & 3.0 & 0.3 & $\rightarrow$ \\
\hline $\begin{array}{l}\text { DT73-9 } \\
(9)\end{array}$ & CI & $\therefore$ & $\cdots$ & 63.3 & $\cdots$ & $\cdots$ & * & 8.0 & $0.3 \mathrm{a}$ & $\cdots$ & $\therefore$ & 5.0 & 23.2 & $\underset{x}{x}$ \\
\hline$M 73-14$ & $\mathrm{CI}$ & $\cdots$ & $\ldots$ & 49.4 & $=$ & $=$ & $\cdots$ & 8.9 & $\cdots$ & $=$ & $\therefore$ & $\cdots$ & 41.8 & 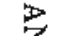 \\
\hline $\begin{array}{c}\text { TKB 2-33 } \\
(10)\end{array}$ & $\mathrm{e}$ & $\cdots$ & $\cdots$ & 50.7 & $\cdots$ & 37.4 & $\cdots$ & 5.3 & $1.3 \mathrm{a}$ & $=-$ & - & 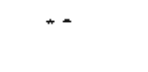 & 25.8 & 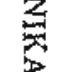 \\
\hline TKB2-57 & $P$ & $=$ & $\ldots$ & 61.4 & $\cdots$ & 8.2 & - & 5.8 & $1.0 \mathrm{a}$ & $\cdots$ & -. &.- & 24.1 & $p$ \\
\hline М73-36B & $\mathbf{P}$ & $\cdots$ & -- & $56.2^{-}$ & - & 8.4 & $\cdots$ & 0.6 & $=$ & $\ldots$ & $\cdots$ & 4.1 & 30.6 & 回 \\
\hline EH5-2A & To & $\cdots$ & - & 55.8 & $\cdots$ & $\ldots$ & -. & 0.9 & - & -- & - & 4.1 & 2.2 & 0 \\
\hline EH5-2B & To & - & . & 7,6 & $\cdots$ & 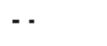 & $\cdots$ & 7.6 & $=$ & $-\cdot$ & $\cdots$ & 1.3 & 82.4 & 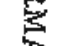 \\
\hline SLL3-6 & $\mathrm{CI}$ & 5.9 & 6.9 & 62.4 & -. & 7.2 & - & 0.7 & Tr a & $\cdots$ & - & $\cdots$ & 27.0 & $\stackrel{?}{7}$ \\
\hline SL13-37 & CI & $\therefore$ & $\therefore$ & 70.2 & -- & 10.4 & $\cdots$ & 2.9 & $0.3 \mathrm{a}$ & 0.6 & - & $\ldots$ & 15.6 & 9 \\
\hline DT7 3-6 & CI & 2.9 & -- & 55.6 & $\ldots$ & $\cdots$ & - & 4.2 & $=$ & 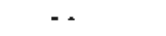 & $=$ & $\cdots$ & 37.4 & \\
\hline$M 73-21 \mathrm{~A}$ & CI & 0.3 & $\cdots$ & 64.7 & $\mathrm{Pr}$ & 9.0 & 2.7 & 2.9 & $0.3 \mathrm{a}$ & 1.3 & $\cdots$ & - & 28.0 & \\
\hline M73-23 & $\mathrm{CI}$ & 5.5 & $\cdots$ & 67.4 & $\cdots$ & 8.5 & $\cdots$ & 3.3 & $0.3 \mathrm{a}$ & $\cdots$ & $\cdots$ & $-\cdot$ & 15.0 & \\
\hline TBK2-12 & $\mathbf{P}$ & 3.0 & 6.1 & 52.1 & $\cdots$ & 6.7 & 1.8 & 3.6 & $\begin{array}{l}\mathrm{Tr} \mathrm{g} \\
3.7 \mathrm{a},\end{array}$ & $\cdots$ & 5.8 & $\cdots$ & 17.1 & \\
\hline TKB2-35 & $\mathbf{P}$ & 2.6 & 8.4 & 57.3 & $\ldots$ & 7.8 & 0.3 & 4.8 & $\begin{array}{l}\text { Trz } \\
1.6 \mathrm{a}\end{array}$ & $=-$ & 0.2 & & 12.3 & \\
\hline EH3-1 & p & $\ldots$ &. .4 & 45.6 & .. & $\begin{array}{r}1.0 \\
16.2\end{array}$ & $\begin{array}{l}2.0 \\
2.6\end{array}$ & $\begin{array}{r}4.8 \\
30.4\end{array}$ & $\begin{array}{l}1.6 \mathrm{a} \\
0.3 \mathrm{a}\end{array}$ & 1.6 & .2 & $\cdots$ & $\begin{array}{r}12.3 \\
4.2\end{array}$ & \\
\hline EH3-11 & $\mathbf{P}$ & - & $\cdots$ & 63.9 & -. & 0.5 & 0.3 & 28.4 & $\therefore$ &.- & $\therefore$ & . & 17.1 & \\
\hline SJ $4-34$ & $\mathbf{P}$ & -. & $\cdots$ & 68.2 & $\therefore$ & 6.2 & 1.3 & 5.3 & $0.3 \mathbf{a}$ & 8.9 & 1.6 & - & 8.2 & \\
\hline $\begin{array}{r}\text { DT73-1 } \\
\text { (11) }\end{array}$ & $\mathbf{P}$ & 2.7 & 3.7 & 58.3 & $\ldots$ & 8.7 & 0.8 & 3.7 & $2.8 \mathrm{a}$ & - & 16.0 & $\ldots$ & 4.3 & \\
\hline$M 73-38$ & $P$ & $\cdots$ & $\cdots$ & 44.6 & 12.1 & 5.4 & 1.6 & 22.9 & $\therefore$ & $\cdots$ & $\cdots$ & $\cdots$ & 13.3 & \\
\hline \multicolumn{15}{|c|}{ 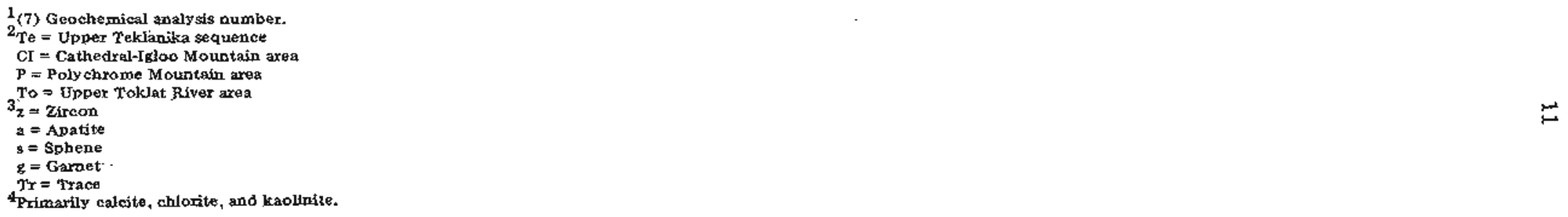 } \\
\hline
\end{tabular}




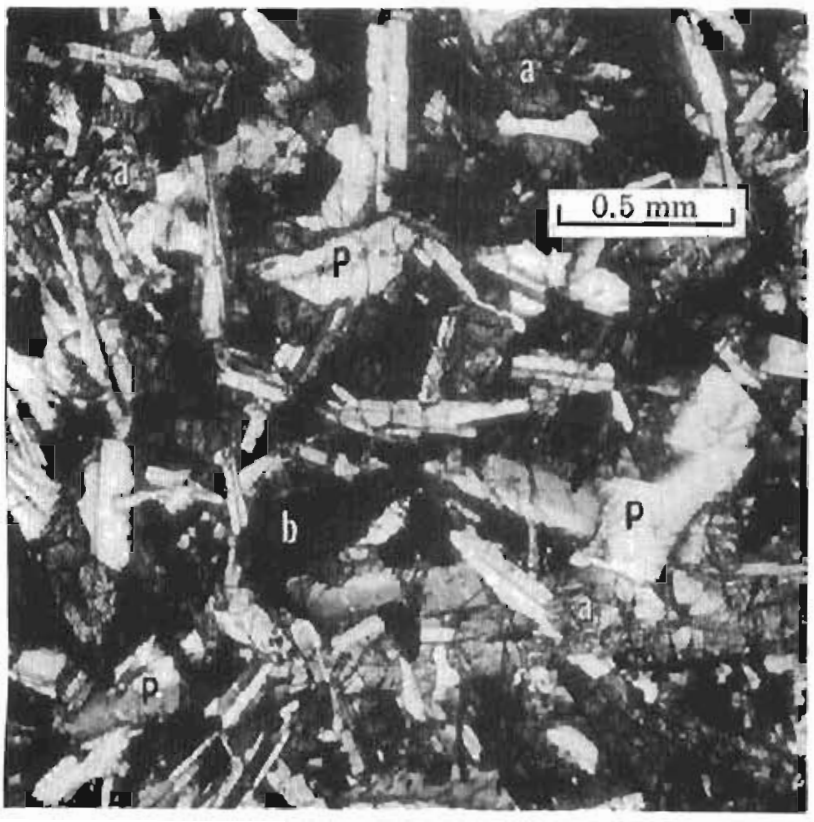

Figure 11. Photomicrograph of andesite flow from Polychrome Mountain. p - plagioclase, a - augite, b - biotite. Crossed nicols.

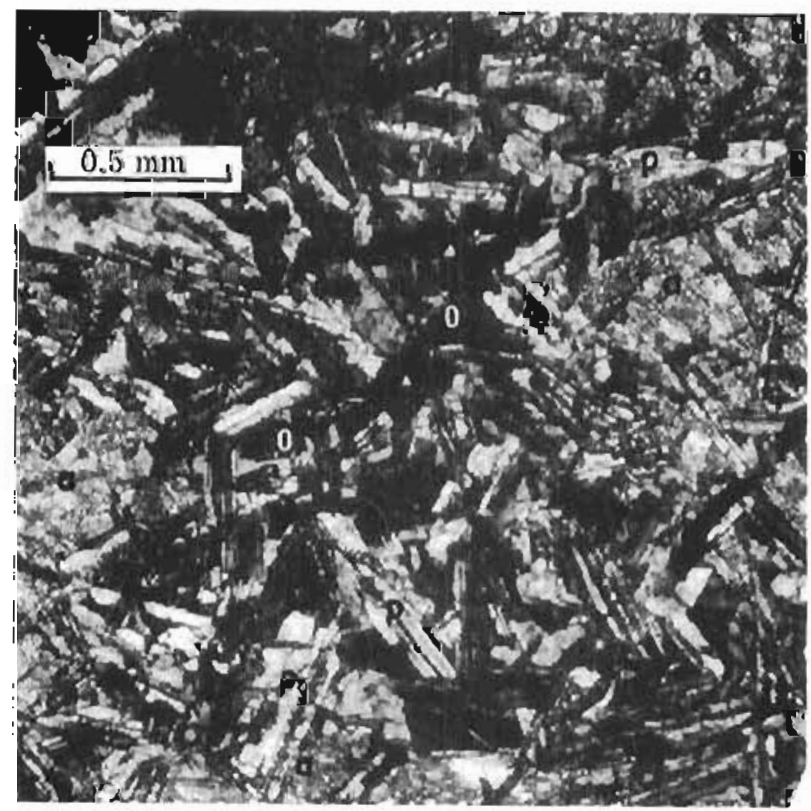

Figure 12. Photomicrograph of andesile llow from unil $\mathrm{E}$ of upper Teklanika sequence. $\mathrm{p}$ - plagioclase, a - augite, o - olivine altering to serpentine and iddingsite. Crossed nicols.

iron enrichment for low alkali values, and a plot of $\mathrm{A}_{2} \mathrm{O}_{3}$ versus normative plagioclase (fig. 16) strongly suggest that the rocks are part of a calc-alkali series rather than a tholeitic basalt series, al hough the $\mathrm{Al}_{2} \mathrm{O}_{3}$ conten $\mathrm{t}$ of basaits and andesites is some whal transitional

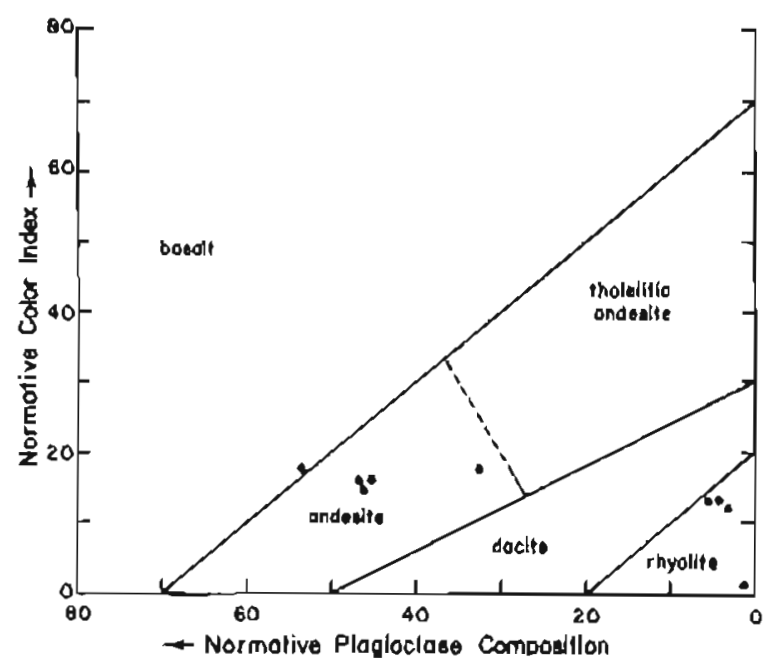

Figure 13. Chemical classification of nine volcanic rocks from Teflanika Formation after Irvine and Baragar, 1971.

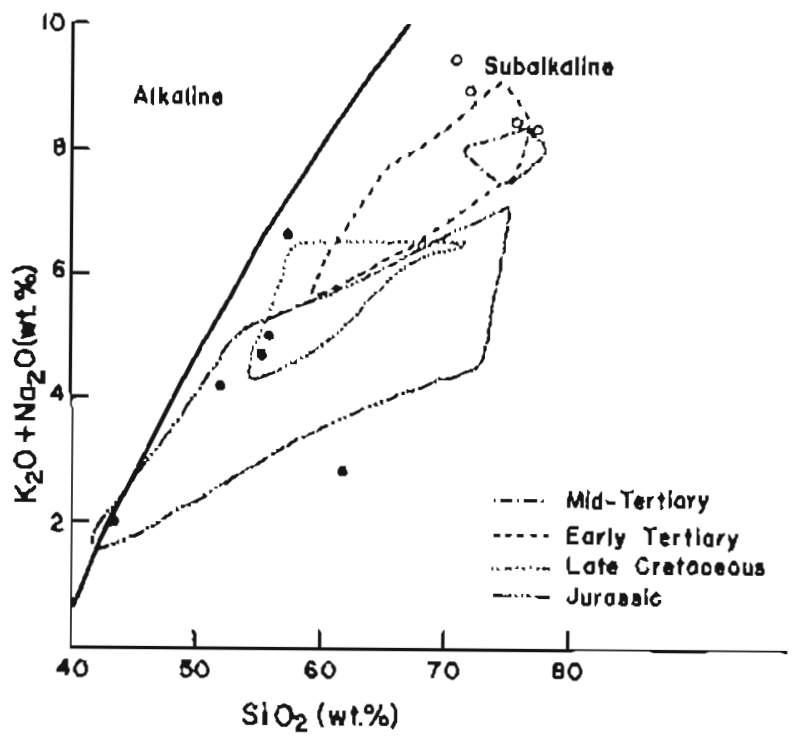

Figure 14. Alkalies-sidica diagram with nine volcanic rocks from Teklanika Formation plotted (solid circles - andesite and basalt; open circles - rhyolite). Solid line separates alkaline and subalkaline rocks arter Irvine and Baragar, 1971. Broken lines enciose chemical trends of plutonic rocks from Alaska. Aleutian Range batholith from Reed and Lanphere. 1973.

belween the two series. The presence of modal augite, quartz, and phenocrysls of pyroxene, olivine, and plagioclase are also consistent with, mineral phases commonly found in calc-alkaline basalts and andesites (Hyndman, 1972).

Because of the generally siliceous nature, low Na-K ratio, lack of iron enrichment, and trace amounts of 
Table 3. Geochemical analyses (rapid rock technique by Skyline Labs, Wheatridge, CO)

and CIPW norm calculations in percent.

\begin{tabular}{|c|c|c|c|c|c|c|c|c|c|c|c|}
\hline \multirow[b]{2}{*}{ Oxides } & \multicolumn{9}{|c|}{ Sample ${ }^{1}$} & \multirow[b]{2}{*}{10} & \multirow[b]{2}{*}{11} \\
\hline & 1 & 2 & 3 & 4 & 6 & 6 & 7 & 8 & 9 & & \\
\hline $\mathrm{SiO}_{2}$ & $\overline{77.49}$ & $\overline{72.06}$ & $\overline{71.03}$ & $\overline{76.04}$ & 71.66 & 61.89 & 55.37 & 56.93 & 57.49 & $\overline{52.16}$ & 53.27 \\
\hline $\mathrm{TiO}_{2}^{2}$ & 0.21 & 0.34 & 0.37 & 0.11 & 0.48 & 1.01 & 2.20 & 1.97 & 1.93 & 2.40 & 2.86 \\
\hline $\mathrm{Al}_{2} \mathrm{O}_{9}$ & 12.68 & 13.91 & 13.81 & 12.51 & 15.04 & 15.53 & 15.05 & 15,17 & 15.85 & 16.76 & 16.63 \\
\hline $\mathrm{Fe}_{2} \mathrm{O}_{3}$ & 0.73 & 4.09 & 4.67 & 2.44 & 0.79 & 0.79 & 1.26 & 0.94 & 3.75 & 4.27 & 5.41 \\
\hline $\mathrm{FeO}$ & 0.10 & 0.05 & 0.18 & 0.12 & 1.77 & 5.44 & 6.90 & 6.81 & 5.89 & 4.38 & 4.45 \\
\hline $\mathrm{MnO}$ & 0.02 & 0.09 & 0.09 & 0.02 & 0.08 & 0.16 & 0.11 & 0.10 & 0.19 & 0.14 & 0.15 \\
\hline $\mathrm{MgO}$ & 0.29 & 0.12 & 0.09 & 0.15 & 1.16 & 5.77 & 5.23 & 4.96 & 1,93 & 5.83 & 2.55 \\
\hline $\mathrm{CaO}$ & 0.33 & 0.19 & 0.45 & 0.22 & 2.60 & 6.44 & 8,68 & 8.67 & 6.00 & 9.58 & 8.27 \\
\hline $\mathrm{Na}_{2} \mathrm{O}$ & 2,66 & 3.28 & 3.56 & 3.26 & 3.63 & 2.33 & 2.93 & 2.89 & 3.22 & 2.82 & 3.71 \\
\hline $\mathrm{K}_{2} \mathrm{O}$ & 5.63 & 6.63 & 5.89 & 5.19 & 2.80 & 0.48 & 1.78 & 2.07 & 3.43 & 1.36 & 2.02 \\
\hline $\mathrm{P}_{2} \mathrm{O}_{5}$ & 0.03 & 0.02 & 0.03 & 0.02 & 0.15 & 0.10 & 0.55 & 0.54 & 0.37 & 0.36 & 0.74 \\
\hline \multicolumn{12}{|l|}{ Norms } \\
\hline Quartz & 87.35 & 28.84 & 25.48 & 34.73 & 31.79 & 24.60 & 4.36 & 3.17 & 9.89 & 2.18 & 4.59 \\
\hline Orthoclase & 33.72 & 93.76 & 35.29 & 31,11 & 16.52 & 2.76 & 10.50 & 12,26 & 20.50 & 8.05 & 12.10 \\
\hline Albite & 24.23 & 29.85 & 32.37 & 29.67 & 32.54 & 20.52 & 26.29 & 26.08 & 29.21 & 25.40 & 33.87 \\
\hline Anorthite & 0.86 & 1.70 & 1.46 & 0.86 & 6.66 & 16.91 & 22.70 & 22.45 & 18.94 & 29.32 & 23.20 \\
\hline Corundum & 2.00 & 2.02 & 1.17 & 1.57 & 3.91 & 5.21 & $\ldots$ & $\ldots$ & $\ldots$ & $\cdots$ & $\ldots$ \\
\hline Diopside & $\ldots$ & $\ldots$ & $\ldots$ & $\ldots$ & $\ldots$ & $\ldots$ & 5.14 & 6.38 & 1.87 & 6.21 & 5.19 \\
\hline \multicolumn{12}{|l|}{ Hypersthene } \\
\hline$e n^{2}$ & 0.80 & 0.32 & 0.23 & 0.40 & 3.15 & 16.62 & 14,44 & 13.75 & 6.39 & 16.20 & 7.14 \\
\hline $\mathrm{fs}^{3}$ & $\ldots$ & $\ldots$ & $\ldots$ & $\ldots$ & 1.62 & 6,58 & 6.92 & 7.35 & 4.16 & 0.68 & $\ldots$ \\
\hline Olivene & $\ldots$ & $\ldots$ & $\ldots$ & $\ldots$ & $\ldots$ & $\ldots$ & $\ldots$ & $\ldots$ & $\ldots$ & $\ldots$ & $\ldots$ \\
\hline Magnetite & $\ldots$ & $\ldots$ & $\ldots$ & 0.07 & 0.82 & 0.81 & 1.31 & 0.99 & 3.97 & 4.49 & 4.79 \\
\hline Ilmenite & 0.16 & 0.19 & 0.40 & 0.14 & 0.59 & 1.38 & 3.06 & 2.75 & 2.72 & 3.36 & 4.05 \\
\hline Apatite & 0.04 & 0.02 & 0.04 & 0.02 & 0.30 & 0.20 & 1.14 & 1.13 & 0.77 & 0.76 & 1.56 \\
\hline Calcite & 0.26 & 0.26 & 0.26 & 0.26 & 2.10 & 5.50 & 1.59 & 0.52 & 1.65 & 0.27 & 0.27 \\
\hline Hematite & 0.51 & 2.90 & 3.29 & 1,68 & $\ldots$ & $\ldots$ & $\ldots$ & $\ldots$ & $\cdots$ & $\ldots$ & 0.64 \\
\hline Rutîle & 0.06 & 0.14 & $\ldots$ & $\ldots$ & $\ldots$ & $\ldots$ & $\ldots$ & $\ldots$ & $\ldots$ & $\cdots$ & $\ldots$ \\
\hline
\end{tabular}

${ }^{1}$ Geocheolcal andy yls number (see tables 1 and 2 ).

3 Enstatlue

Table 4. Analytical dala for $K \cdot$ Ar age determinations.

\begin{tabular}{|c|c|c|c|c|c|c|c|c|}
\hline Sample & Rock type & $\begin{array}{l}\text { Minetal } \\
\text { dated }\end{array}$ & $\begin{array}{l}\mathrm{K}_{2} \mathrm{O} \\
\text { (weight } \\
\text { percent) }\end{array}$ & $\begin{array}{l}\text { Sample } \\
\text { weight } \\
(\mathrm{gm})\end{array}$ & $\begin{array}{l}{ }^{40} \text { Arjad } \\
\text { (molesfgm) } \\
x 10^{-11}\end{array}$ & $\begin{array}{l}40_{\mathrm{Ar}}{ }_{\text {rad }} \\
40_{\mathrm{K}} \\
\times 10^{-2}\end{array}$ & $\frac{40 \mathrm{Ar}_{\text {rad }}}{40 \mathrm{Ar}_{\text {total }}}$ & $\begin{array}{c}\text { Age } \pm 2 \sigma \\
(\mathrm{m} . \mathrm{y} .)\end{array}$ \\
\hline $\begin{array}{l}\text { DT-73-9 } \\
\text { DT-73-1 }\end{array}$ & $\begin{array}{l}\text { andesite } \\
\text { quartz diorite }\end{array}$ & $\begin{array}{l}\text { plagioclase } \\
\text { plagioclase }\end{array}$ & $\begin{array}{l}0.600,0.610 \\
0.320,0.317\end{array}$ & $\begin{array}{l}4.4935 \\
3.6977\end{array}$ & $\begin{array}{r}24.73 \\
2.74\end{array}$ & $\begin{array}{l}0.3600 \\
0.3400\end{array}$ & $\begin{array}{l}0.812 \\
0.661\end{array}$ & $\begin{array}{l}60.6 \mathrm{Min} \\
57.2+3.4\end{array}$ \\
\hline 74 WG-14 & basale & whole rock & $2.30,2.30$ & 1.9480 & 14.36 & 0.2472 & 0.480 & 41.8 Min. \\
\hline
\end{tabular}

Constants used in age calculations:

$\lambda_{\varepsilon}=0.585 \times 10^{-10} / \mathrm{yr}$

$\lambda_{d}^{\varepsilon}=4.72 \times 10^{-10} / \mathrm{yr}$

$\mathrm{K}^{40 / \mathrm{K} \text { tolal }=1.19 \times 10^{-4} \text { mole } / \text { mole }}$

garnet, the Teklanika formation may have been produced by eclogite-controlled fractionation at a depth greater than 100 kilometers (Ringwood, 1974). The bimodal charactey of the formation may be caused by contemporaneous fractionation in the mantle of hydrous parental material into two contrasting magmas as sug. gested by Yoder (1973).

Figure 14 also reproduces the chemical trends of 199 


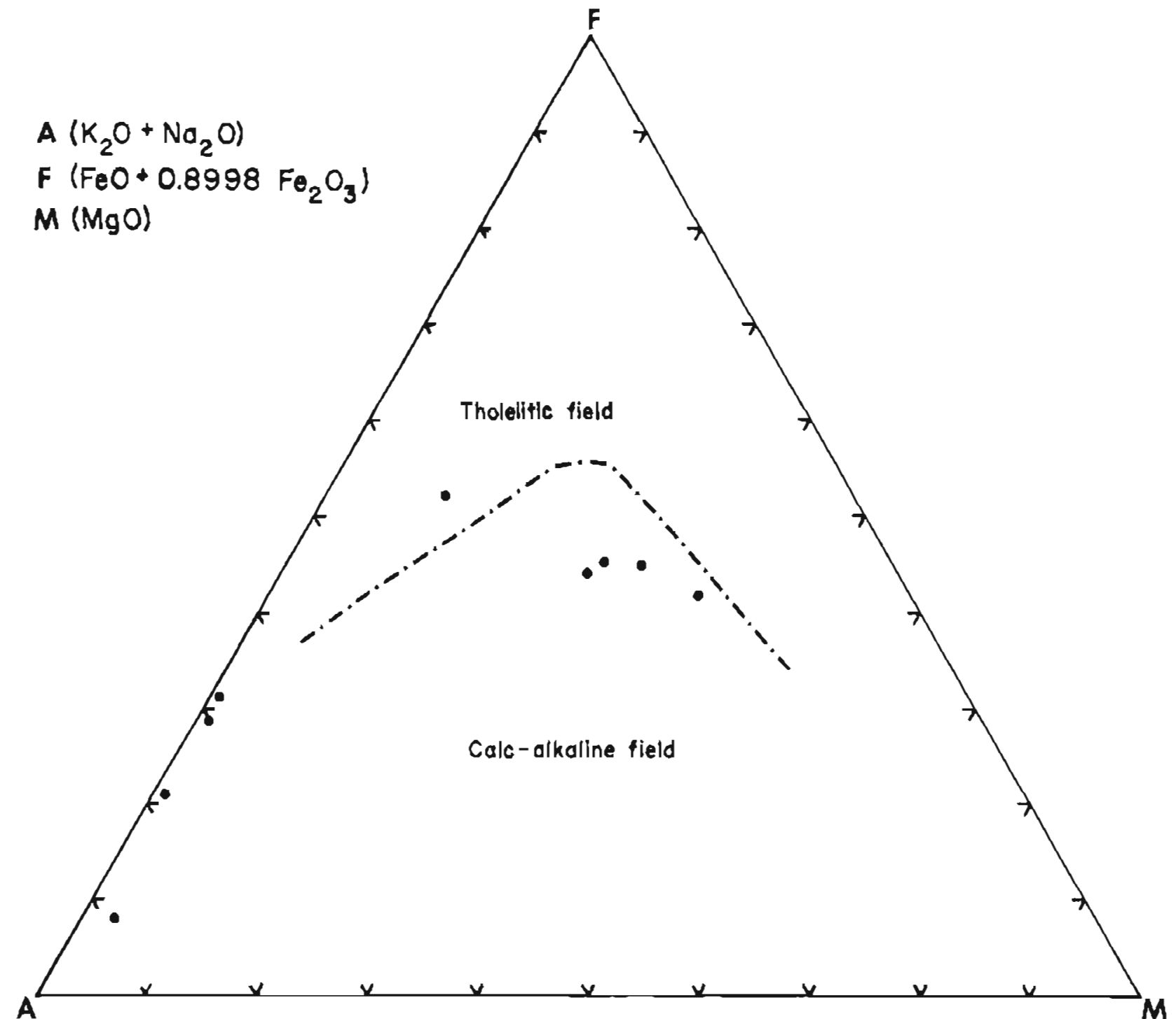

Figure 15. AFM diagram with nine volcanic rocks from Teklanikn Formation plotted. Broken line separates tholeiitic and calc-alkaline rocks after Irvine and Baragar, 1971.

plutonic rock samples from the Alaska-Aleutian Range batholith published by Reed and Larphere (1973). The dlagram vaguely suggests that the rhyolite flows of the Paleocene Telanika Formation may be cogenetic with early Tertiary granitic rocks of equivalent age in south-eentral Alaska, although more petrologic and chemical studies are needed.

\section{GEOCHRONOLOGY}

Radiometric ages of two volcanic and one related plutonic rock were delermined by the potassium-argon method (analytical data reported in table 4; see Tumer and others, 1973, for discussion of analytical method used). Pragioclase from the andesite flow on Cathedral Mountain (DT-73.9) yielded a minimum age of 60.6 m.y. A whole-rock sample from a basalt flow in the upper East Fork drainage yieided a minimum age of $41.8 \mathrm{~m} . y$. These two dates must be considered minimum ages because incipient alteration is likely to have caused postcrystallization argon loss. Plagioclase from the quartz-diorite plug on Polychrome Mountain (DT-73-1) ylelded an age of $57.2 \pm 3.4 \mathrm{~m} . \mathrm{y}$.

Five whole-rock potassium-argon ages from the Teklanika Formation to the east (Hickman, 1974) range from $49.5 \pm 2.1 \mathrm{~m} . \mathrm{y}$. to $59.3 \pm 2.7 \mathrm{~m} . \mathrm{y}$. Alteration is reported from these rocks also, and their ages must be considered minlmum ages for Teklanika Formation volcanism.

All these dates suggest that eruption of the Teklanlka Formation took place during Paleocene ltme. Because the Teklanika Formation is closely associated in time 
and space with the underlying Cantwell Formation, the radiometric ages give a minimum age for the deposition of the Cantwell Formation as well. The age dates agree with paleobotanical dating of the Cantwell Formation (Wolfe and Wahrhaftig, 1970; Wolfe, 1972), which indicates that the formation is Paleocene in age; they also agree with a maximum age of the Cantwell Formation to the east of 95 m.y. (Wahrhaftig and others, 1975). Thus, a closely spaced series of events, beginning with deposition of the Cantwell Formation and ending with orogeny and its associated calc-alkaline volcanisin (Gilbert, 1975), occurred during Paleocene time in the central Alaska range.

\section{ACKNOWLEDGMENTS}

The authors wish to thank the National Park Service, in particular Daniel Kuehn and Vernon Ruesch, superintendents at Mount McKinley National Park, for their cooperation with our field studies.

We also appreciate the field assistance of the follow. ing members of the 1972 and 1973 University of Alaska geology departmenl camps: Edward Anderson, Enayat Azlz, Thomas K. Bundtzen, Charles Collins, Floyd Demman, Richard Droker, Ronald Edquisl, Dennis Erickson, Carmen Fischer, Robert Gaddis, Richard Jirik, Steve Johnson, Steve Lowell, James A. Madonna, Patricia Potts, Earl Redman, William Roberts, Mark Robinson, James Robar, Ernest Sloan, and Mark Zdep. ski.

In addition, special thanks are due to Bundtzen, Robert B. Forbes, and Florence R. Wober for heipful discussions and criticism, and to John W. Buza for assistance during the 1974 field season.

\section{REFERENCES CITED}

Brooks, A.H., 1911, The Mount McKinley Region, Alaska: U.S. Geol. Survey Pror. Paper 70, 234 p.

Burk, C.A., 1965, Geology of the Alaska Peninsulaisland arc and continental margin; Geol. Soc. Am. Mem. 99, 250 p.

Capps, S.R., 1919, The Kantishna region, Alaska: U.S. Geol. Survey Bull. 687, $112 \mathrm{p}$.

1930, The eastern portion of Mount McKinley National Park: U.S. Geol. Survey Bull. 836-D. p. 236 . 300.

- 1940, Geology of the Alaska Railroad region: U.S. Geol. Survey Bull. 907, 201 p.

Coats, R.R., 1962, Magma type and crustal structure in the Aleutian Arc, in The crust of the Pacific Basin: Am. Geophys. Union Geophys. Mon. 6, p. 92-109.

Decker, J., 1975, Geology of the Mount Galen area, Mount McKinley National Park, Alaska: College, AK, Univ. of Alaska M.S. thesis, 77 p.

Eldridge, G.H., 1900, A reconnaissance in the Susitna Basin and adjacent territory, Alaska, in 1898: U.S. Geol. Survey 20th Ann. Rept., pt. 7, p. 1-29.

Gabrielse, H., 1967, Tectonic evolution of the northern

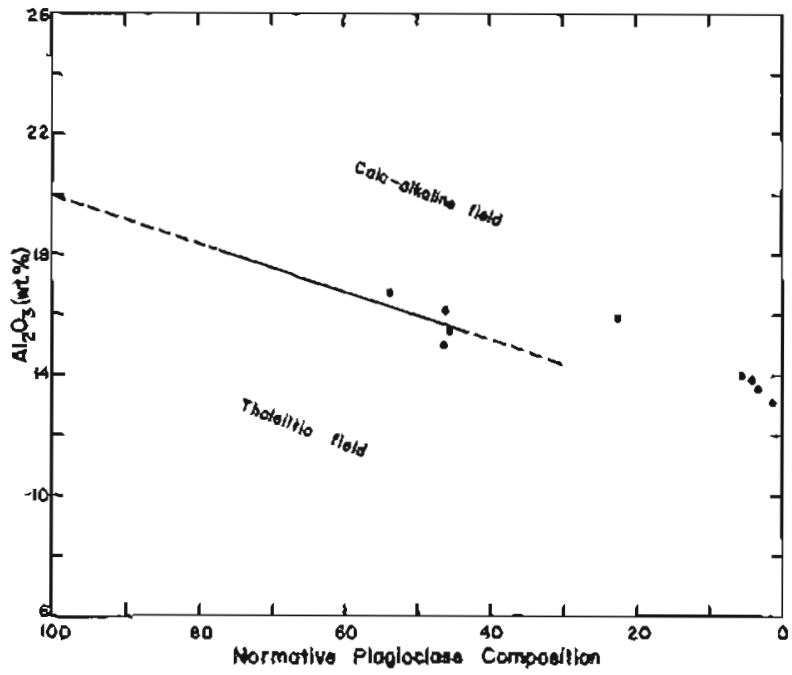

Figure 16. $\mathrm{Al}_{2} \mathrm{O}_{3}$ - Normative plagioclase diagram with nine volcanic rocks from Teklanika Formation plotted. Solid and broken line separates calc-alkaline and tholeiitic rocks after Irvine and Baragar, 1971

Canadian Cordillera: Canadian Jour. Earth Sci., 4: 271-298.

Gilbert, W.G., 1975, Outline of tectonic history of west-central Alaska Range: Geol. Soc. America Abs. with Programs, Cordilleran section, p. 320.

Gilbert, W.G., and Redman, E., 1975, Geologic map and structure sections of the Healy C-6 quadrangle, Alaska: Alaska Div. Geol. and Geophys. Surveys open file rept. AOF- 80 .

Green, T.H., and Kingwood, A.E., 1968, Genesis of the calc-alkatine igneous rock suite: Contr. Mineralogy and Petrology 18, p. 105-162.

Hickman, R.G., 1974, Structural geology and stratigraphy along a segment of the Denali Fault system, central Alaska Range, Alaska: Madison, WI, Univ. of Wisconsin Ph.D. thesis, 276 p.

Hyndmann, D.W., 1972, Petrology of igneous and metamorphic rocks: New York, McGraw-Hill Book Co.

Irvine, T.N., and Baragar, W.R.A., 1971, A guide to the chemical classification of common volcanic rocks: Canadian Jour. Earth Sci., 8:523.548.

Jakes, P. and White, A.J.R., 1972, Major trace element abundances in volcanic rocks of orogenic areas: Geol. Soc. America Bull, v. 83, p. 29-40.

Lathram, E., 1973, Tectonic framework of northern and central Alaska, in Arctic geology (M. Pilcher, ed.): Am. Assoc. Petroleum Geologists Mem. 19, p. $351-360$.

Monger, J.W., Souther, J.G., and Gabrielse, H., 1972. Evolution of the Canadian Cordillera.A plate tectonic model: Am. Jour. Sci, 272:577-602.

Peterson, D.W, 1961, Descriptive model classification of igneous rocks, Am, Geol. Irist, data sheets, $23 a-23 c$.

Redman, E., 1974, Geology of the Wyoming Hilts, Mount McKinley National Park, Alaska: College, AK, Univ. of Alask a M.S. thesis, 61 p. 
Reed, B.L, and Lanphere, M.A., 1973, Plutonic rocks of the Alaska-Aleutian Range Batholith, in Arctic geology (M. Pitcher, ed.): Am. Assoc. Petroleurn Geologists Mem, 19, p. 421-427.

Reed, J.C., Jr., 1961, Geology of the Mount McKinley quadrangle, Alaska: U.S. Geologic Survey Bull, 1108A, $36 \mathrm{p}$

Ringwood, A.E., 1974, The petrologic evolution of island are systems: Geol. Soc. London Quart. Jour., 130: 183-204

Souther, J,G., 1967, Acid rolcanism and its relationship to the tectonic history of the Cordillera of British Columbia, Canada: Bull. Volcanol., 30:161-176.

Turner, D.L., Forbes, R.B, and Naeser, C.W., 1973, Radiometric ages of Kodiak Seamount and Giacomini Guyot, Gulf of Alaska-Implications for
circum-Pacific tectonics, Science, v. 182 , p. 579, 581.

Wahrhaftig, C., Turner, D.L., Weber, F.R., and Smith, T.E., Nature and time of movement on Hines Creek strand of Denali Fault system, Alaska: Geology, v. 3, no. 8, p. 469-466.

Wolfe, J.A., 1972, An interpretation of Alaskan Tertiary floras: Floristics and paleofloristics of Asia and eastern North America (A. Graham, ed.), Elsevier Publishing Co., Amsterdam, p. 201-239.

Wolfe, J,A, and Wahrhaftig, C, 1970, The Cantwell Formation of the central Alaska Range, in Changes in stratigraphic nomenclature by the U.S. Geological Survey, 1968: U.S. Geol. Survey Bull. 1794-A, p. A41 A49.

Yoder, H.S., 1973, Conlemporaneous basaltic and rhyolitic magmas: Am. Mineralogist, 58:153-171. 